\title{
Human Germ Cell Tumors are Developmental Cancers: Impact of Epigenetics on Pathobiology and Clinic
}

\author{
João Lobo $\left.{ }^{1,2,3} \mathbb{(}\right)$, Ad J. M. Gillis ${ }^{4,5}$, Carmen Jerónimo ${ }^{1,3} \mathbb{D}$, Rui Henrique ${ }^{1,2,3} \mathbb{D}$ \\ and Leendert H. J. Looijenga $4,5, * \mathbb{D}$ \\ 1 Cancer Biology and Epigenetics Group, Research Center of Portuguese Oncology Institute of Porto \\ (GEBC CI-IPOP), R. Dr. António Bernardino de Almeida, 4200-072 Porto, Portugal; \\ joaomachadolobo@gmail.com (J.L.); carmenjeronimo@ipoporto.min-saude.pt (C.J.); \\ henrique@ipoporto.min-saude.pt (R.H.) \\ 2 Department of Pathology, Portuguese Oncology Institute of Porto (IPOP), \\ R. Dr. António Bernardino de Almeida, 4200-072 Porto, Portugal \\ 3 Department of Pathology and Molecular Immunology, Institute of Biomedical Sciences Abel Salazar, \\ University of Porto (ICBAS-UP), Rua Jorge Viterbo Ferreira 228, 4050-513 Porto, Portugal; \\ 4 Laboratory of Experimental Patho-Oncology (LEPO), Josephine Nefkens Building, Erasmus MC, \\ Department of Pathology, University Medical Center, Cancer Institute, Be-432A, PO Box 2040, \\ 3000 CA Rotterdam, The Netherlands; a.gillis@erasmusmc.nl \\ 5 Princess Máxima Center for Pediatric Oncology, Heidelberglaan 25, 3584 CS Utrecht, The Netherlands \\ * Correspondence: 1.looijenga@prinsesmaximacentrum.nl; Tel.: +31-88-972-5211
}

Received: 7 December 2018; Accepted: 7 January 2019; Published: 10 January 2019

\begin{abstract}
Current (high throughput omics-based) data support the model that human (malignant) germ cell tumors are not initiated by somatic mutations, but, instead through a defined locked epigenetic status, representative of their cell of origin. This elegantly explains the role of both genetic susceptibility as well as environmental factors in the pathogenesis, referred to as 'genvironment'. Moreover, it could also explain various epidemiological findings, including the rising incidence of this type of cancer in Western societies. In addition, it allows for identification of clinically relevant and informative biomarkers both for diagnosis and follow-up of individual patients. The current status of these findings will be discussed, including the use of high throughput DNA methylation profiling for determination of differentially methylated regions (DMRs) as well as chromosomal copy number variation (CNV). Finally, the potential value of methylation-specific tumor DNA fragments (i.e., XIST promotor) as well as embryonic microRNAs as molecular biomarkers for cancer detection in liquid biopsies will be presented.
\end{abstract}

Keywords: biomarkers; development; epigenetics; germ cell cancer; methylation; microRNAs; testicular cancer

\section{Introduction: Germ Cell Tumors in General}

\subsection{Epidemiology}

A number of different cell types can be found in the testis (germ cells, Sertoli cells, Leydig cells, mesenchymal cells, mesothelial cells, among others); thus, and despite being a relatively small organ, the testis may give rise to a large variety of neoplasms. Nonetheless, more than $95 \%$ of testicular neoplasms are derived from germ cells arrested in their differentiation-the testicular germ cell tumors (TGCTs) [1] —meaning that global epidemiological trends for testicular cancer mostly refer to this group of neoplasms. Still, germ cell tumors (GCTs) are not simply a single class of neoplasms; instead, 
they represent a heterogeneous array of tumor entities, arising either in the gonads (both male and female) or being extragonadal (developing from germ cells arrested in their migration along the midline of the body), reflecting a complex and development-related tumor model, each subclass showing its peculiarities and specific epidemiology. The European Cancer Registry-Based Study on Survival and Care of Cancer Patients (EUROCARE) reports markedly distinct age-adjusted incidence rates of GCTs in Europe for males and females (64 per 1,000,000 versus 4 per 1,000,000, respectively) [2]; besides these global differences in incidence, there are histological divergences among testicular and ovarian neoplasms: in males most tumors are seminomas (SEs) and most non-seminomatous tumors (NSTs) are mixed forms, while in women most tumors are NSTs and mixed forms are the exception. TGCTs show a 'bell-shaped' distribution of cases with a peak around 30 years, with SEs overall occurring 10 years later than NSTs. In the United States incidence rates were of 56 per 1,000,000 and of only 10 per 1,000,000 in Caucasian and African-American males, respectively [3]. Only 4\% of GCTs are extragonadal, located at central nervous system, mediastinum, retroperitoneum, and pelvis, and the majority correspond to NSTs. Incidence of GCTs overall has been increasing, especially at the expense of TGCTs. Five-year survival is better for gonadal GCTs when compared to extragonadal GCTs [2].

Overall, testicular cancer is not a common disease, ranking as only the 21st most incident neoplasm in men worldwide, in 2018 (with 71,105 new cases and an age standardized rate of 1.7 per 100,000). It is neither a frequent cause of cancer-related deaths, being the 27 th most lethal malignancy in men (with 9,507 estimated deaths in 2018). However, a closer look at the figures shows it also represents the most incident and most prevalent neoplasm in males aged 15-39 years old, at global level, with an age-standardized incidence rate of 2.7 per 100,000 in 2018 and a five-year prevalence of 150,377 cases. Moreover, incidence is on the rise in most populations [4], with a total of 85,635 new cases expected for 2040 (14,530 more that in 2018, representing a $20.4 \%$ increase), and a total of 13,288 estimated deaths (3781 more than in 2018, a 39.8\% increase), according to Globocan 2018 predictions [5]. Similar data is replicated by the Surveillance, Epidemiology, and End Results Program (SEER) database; despite representing only $0.5 \%$ of all new cancer cases in the United States, incidence rates have been rising $0.8 \%$ per year over the last 10 years and the number of new cases of testicular cancer was 5.7 per 100,000 males per year according to 2011-2015 registries. Median age at diagnosis is 33 years-old ( 25 years for NSTs, 35 years for SEs) and an intermediate 30 years for NSTs with a SE component). The majority $(68 \%)$ of patients are diagnosed with localized disease $(>80 \%$ of SEs and $>60 \%$ of NSTs present with clinical stage I disease). Metastases emerge in $15 \%$ and $20 \%$ of stage I SE and NST patients, respectively, within a period of two to three years [1]. Still, five-year survival is outstanding (95.3\%), even for patients diagnosed with distant metastases overall (73.7\%) [6-8]. Importantly, variation in testicular cancer incidence rates worldwide is remarkable (29-fold variation, being higher in Europe, Australia and the United States), and mortality-to-incidence ratio is reported to be higher in underdeveloped regions of the globe, probably due to less access to proper healthcare facilities, diagnostic tools, and multimodal treatments [9]. This information is summarized in Table 1 below.

Table 1. Epidemiology of germ cell tumors: incidence, prevalence, and mortality data.

\begin{tabular}{|c|c|c|}
\hline Statistics & Context & Source \\
\hline $\begin{array}{l}\text { Age adjusted incidence rates: } 64 / 1,000,000 \text { (males) versus } \\
\qquad 4 / 1,000,000 \text { (females) }\end{array}$ & Germ cell tumors & Europe (EUROCARE) \\
\hline $\begin{array}{c}\text { Incidence rates: } 0.8 \% \text { rise/year } \\
\text { Estimated new cases: } 5.7 / 100,000 / \text { year (all males, 2011-2015) }\end{array}$ & Testicular cancer & $\begin{array}{l}\text { United States of America } \\
\text { (SEER) }\end{array}$ \\
\hline $\begin{array}{l}\text { Age-standardized incidence rate: } 1.7 / 100,000 \text { (all males) versus } \\
\quad 2.7 / 100,000 \text { (males aged } 15-39 \text { years) } \\
\quad \text { 5-year prevalence: } 150,377 \text { cases (males aged } 15-39 \text { years) } \\
\text { Estimated new cases }(85,635) \text { and deaths }(13,288) \text { in } 2040 \text { (all males) }\end{array}$ & Testicular cancer & World (Globocan) \\
\hline
\end{tabular}

All in all, there are a number of reasons to remain focused on TGCTs: besides the rising incidence in part explained by Western lifestyle, about $15-20 \%$ of patients with disseminated disease experience disease recurrence (with late relapses displaying poor prognosis); in spite of exquisite sensitivity to 
cytotoxic agents, resistance to cisplatin treatment eventually emerges in some cases, by still elusive mechanisms; and also the diagnosis of cancer in such young patients (with long life-expectancy) who undergo chemo and radiotherapy raises concerns over quality of life, fertility and enduring treatment-related side effects, such as the emergence of second tumors and cardiovascular disease, and merit proper action to prevent them [10-15].

\subsection{The 'Genvironmental' Model}

TGCTs constitute a formidable example of how genetic and environmental risk factors can synergistically potentiate malignant transformation, in a so-called 'genvironmental' model [16].

\subsubsection{Genetic Risk Factors}

Genetic factors play an important role in TGCTs genesis; in fact, they contribute to more than $40 \%$ of TGCTs (the third highest rate among all cancer types) [17-19]. Familial risk is one of the highest in cancer: having a brother or father diagnosed with a TGCT increases the risk eight-to-ten and four-to-six times, respectively; the risk in monozygotic and dizygotic twins is increased 76 and 35 times, respectively [20-22]. Also, there is an increased risk for developing cancer in the contralateral testis, which further strengthens the influence of genetic factors and may justify performing biopsies of the contralateral testis for identifying germ cell neoplasia in situ (GCNIS) [23,24]. Familial TGCT (FTGCT) is indeed nowadays well recognized [25], as is the risk association with specific variants of disorders of sex development (DSDs), also referred to as difference of sex development [26-30]. Still, more than $90 \%$ of TGCT patients end up showing no family history of TGCT. Evidence points towards the influence of various autosomal recessive low-penetrance susceptibility genes and polymorphic gene variants. Importantly, a model of true interplay between environmental and genetic factors is the most likely scenario in TGCTs the 'genvironment'. This model fits TGCTs genesis and places epigenetic deregulation as the perfect culprit mechanism for mediating this environment-genetics interaction and for explaining clinical findings that compose the TDS and that associate with increased risk of TGCTs $[16,31,32]$. Over the years, a great effort (in the form of genome-wide association studies (GWAS) and various metanalyses) has been put towards characterizing susceptibility alleles for TGCTs emergence and, to date, a number of these have been determined, the ones showing the highest odds ratio thus far being the KITLG-related [33-36]. Recently, a couple of metanalyses have extended the number of susceptibility risk loci to 44 . Importantly, these studies have put in evidence the polygenic character of the TGCT tumor model, identifying candidate culprit single nucleotide polymorphisms (SNPs) implicated in several distinct pathways, from the well-known KIT-KITL to DNA damage repair (namely $R A D 51 C$ and BRCA1), from sex determination/germ cell specification (namely DMRT1, ZFPM1, and PRDM14) to apoptosis/cell cycle (including GSPT1 and CHEK2), from telomere maintenance (including TERT and ATFIP) to centrosome organization/microtubule assembly (TEX14, PMF1, and CENPE) [17,19,37]. Additionally, novel susceptibility markers have been pointed out by non-GWAS studies, such as $L R R C 50$, being a member of cilia-microtubule genes, also known as DNAAF1 [38,39].

\subsubsection{Environmental Risk Factors}

Environmental risk factors can be categorized into distinct groups: the internal, less-modifiable, developmental/medical risk factors and the external, modifiable, post-natal risk factors.

\section{Internal Risk Factors}

Overall, one can say that features comprising testicular dysgenesis syndrome (TDS) increase the risk of TGCTs [40]; indeed, the most consistent risk factor for TGCT development is cryptorchidism, increasing the risk in about five-fold [41], and other disorders such as hypospadias, testicular atrophy, inguinal hernia, and impaired spermatogenesis are risk factors as well [42]. Other risk factors include perinatal factors, such as low and high birthweight, decreased gestational age, maternal bleeding, 
and low parity. The unifying state among some of these factors is fetal exposure to estrogens and anti-androgens, resulting in disruption of endogenous hormone signaling prenatally by exposure to xenobiotics, leading to undervirilization of the male embryo in utero [43].

\section{External Risk Factors}

Other less established and not so well understood risk factors act postnatally; the contribution of these factors has been assessed in several studies, achieving different and sometimes opposing conclusions. However, although TGCTs emerge early in life, a potential role of these postnatal risk factors cannot be ignored. These include diet (high in fat and dairy products, putting natural or synthetic hormones as culprits), low physical exercise, environmental/occupational exposures (with increased risk in firefighters and metal, leather, and agricultural workers) and also testicular trauma [44]. Most studies found no association with body mass index, while most describe an association with tall stature. Late onset of puberty has been proposed to decrease risk. Marijuana smoking is of particular interest, since it preferentially associates with NST histology, suggesting a role in the reprogramming process $[45,46]$. The reason of the other risk factors to be predominantly acting during intra-uterine development compared to marijuana use remains to be elucidated.

\subsubsection{Interplay between Environmental and Genetic Risk Factors: The 'Genvironment'}

An interplay between the aforementioned genetic and environmental factors has been demonstrated to occur in various studies on TGCTs, with epigenetics serving as a bridge between these two aspects of the disease. This is illustrated, for instance, by the spectrum of clinical manifestations that is TDS. There is an association between infertility and TGCT risk, and also GCNIS lesions are found more often in infertile men when compared to the remaining population, reflecting this link between (in)fertility, andrological/urological abnormalities and TGCT risk, the latter being modified by a complex array of 'genvironmental' modifiers.

A summary of the role of these risk factors is depicted in Table 2.

Table 2. Genetic and environmental risk factors for germ cell tumors.

\begin{tabular}{|c|c|}
\hline Factor & Relative Risk OR \\
\hline \multicolumn{2}{|l|}{ Genetic } \\
\hline \multicolumn{2}{|l|}{ Familial risk } \\
\hline Brother with TGCT & $8-10 x \mathrm{~s}$ \\
\hline Father with TGCT & $4-6 \mathrm{xs}$ \\
\hline \multicolumn{2}{|l|}{ Studies in twins } \\
\hline Monozygotic twins & $76 \times \mathrm{s}$ \\
\hline Dizygotic twins & $35 \mathrm{xs}$ \\
\hline Contralateral tumor & $24.8-27.6$ \\
\hline \multicolumn{2}{|l|}{ Various SNPs } \\
\hline KITLG-related & $\mathrm{OR}>2$ or $<0.5$ \\
\hline \multicolumn{2}{|l|}{ Environmental } \\
\hline \multicolumn{2}{|l|}{ Internal } \\
\hline Cryptorchidism & $3.5-17.1$ \\
\hline Infertility & $1.16-6.72$ \\
\hline Hypospadias & $1.26-3.61$ \\
\hline Atrophy & 20.5 \\
\hline Previous inguinal hernia & 1.63 \\
\hline Microlithiasis & $3.42-13.2$ \\
\hline Disturbed hormonal conditions in utero (maternal bleeding, first born child, low and high birthweight, short gestational age) & $\sim \sim 1.3$ \\
\hline Low birthweight & OR 1.28 \\
\hline Number of siblings $\geq 5$ & OR 0.71 \\
\hline \multicolumn{2}{|l|}{ External } \\
\hline High body mass index & $\uparrow / \downarrow /-$ \\
\hline High stature & $\uparrow /-$ \\
\hline Late onset of puberty & $\downarrow$ \\
\hline Diet high in fat and dairy products & $\uparrow$ \\
\hline Low physical exercise & $\uparrow / \downarrow /-$ \\
\hline Firefighters, metal/leather/agricultural workers & $\uparrow$ \\
\hline Testicular trauma & $\uparrow$ \\
\hline Marijuana smoking & OR 1.7 \\
\hline
\end{tabular}

Abbreviations: KITLG—KIT-ligand; OR—odds ratio; TGCT—-testicular germ cell tumor. 


\subsection{Classification}

The first attempt to classify the various subtypes of TGCTs was accomplished by Friedman and Moore in 1946, when they organized tumors into four groups: SEs, embryonal carcinomas (ECs), teratomas (TEs), and teratocarcinomas [47]. Since then a multitude of classifications have been proposed, reflecting a progressive better understanding of TGCTs tumorigenesis. The most recent 2016 World Health Organization (WHO) Classification is settled on the concept of GCNIS, and recognizes two major types of tumors: the GCNIS-related postpubertal-types, corresponding to SEs and NSTs, and the GCNIS-unrelated neoplasms, comprising both prepubertal-type tumors (i.e., TEs and yolk sac tumors (YSTs) and spermatocytic tumor (ST), previously known as spermatocytic seminoma) [1,48]. With this classification we have witnessed a transition from an essentially morphological system into one that reflects TGCTs pathogenesis and the developmental potential of the cells from which they derive. It is, indeed, an improvement from the former 2004 classification, which considered morphologically similar but very distinct entities under the same group, such as the former historically erroneous designation "spermatocytic seminoma" [49].

Novel and more profound understanding of mechanisms regulating embryogenesis and implicated in germline allow for postulating a developmental model for GCTs in general, based on a biologically plausible, sound and clinically relevant basis for classification. This way, Oosterhuis and Looijenga proposed a new broad classification of GCTs, according to their developmental potential (Table 3) [50]. The classification considers seven types of GCTs, adding type 0 (included and parasitic twins) and type VI (arising from somatic cells which are induced to pluripotency) to the previous five groups already acknowledged by these authors [51]. 
Table 3. Proposed classification of testicular germ cell tumors, according to their developmental state (adapted from [50]).

\begin{tabular}{|c|c|c|c|c|c|c|c|}
\hline GCT Type & Age Group & Sex & Site & Phenotype & Developmental State & Precursor Cell & GI \\
\hline 0 & Neonates & $\mathrm{F} / \mathrm{M}$ & Midline & $\begin{array}{c}\text { Included and parasitic } \\
\text { twins }\end{array}$ & Omnipotent (2C state) & Blastomere & BiP \\
\hline $\mathrm{I}$ & $<6$ years & $\mathrm{F} / \mathrm{M}$ & Gonads, midline & TE, YST & Pluripotent (primed state) & Methylated PGC/gonocyte & BiP to partially erased \\
\hline II & Postpubertal & $>>\mathrm{M}$ & Gonads, midline & SE/Dysg, NST & Totipotent (naive state) & Hypomethylated PGC/gonocyte & Erased \\
\hline IV & Postpubertal & $\mathrm{F}$ & Ovary & Dermoid cyst & Maternally imprinted $2 \mathrm{C}$ state & Oogonia / oocyte & Partially to complete Maternal \\
\hline $\mathrm{v}$ & Postpubertal & $\mathrm{F}$ & Placenta, uterus & Hydatidiform mole & Paternally imprinted $2 \mathrm{C}$ state & Empty ovum / spermatozoa & Completely paternal \\
\hline VI & $>60$ years & $\mathrm{F} / \mathrm{M}$ & Ovary, atypical sites & $\begin{array}{l}\text { Resembling type I or NST } \\
\text { components of type II }\end{array}$ & $\begin{array}{l}\text { Primed state or NST lineages of naive } \\
\text { state }\end{array}$ & Somatic cell induced to pluripotency & Pattern of originating cell \\
\hline
\end{tabular}

Abbreviations: BiP—biparental; Dysg—dysgerminoma; F—female; GCT—germ cell tumor; GI—genomic imprinting; M—male; NST-non-seminomatous tumors; PGC—primordial germ cell; SE—seminoma; ST—spermatocytic tumor; TE—teratoma; YST—yolk sac tumor. 
In this review, we will be focusing especially on type II GCTs occurring in the testis, which are the most frequent, the most histologically and clinically diverse and the most extensively studied [18]. However, some of the topics to be discussed are also of relevance for some of the other types of GCTs.

\section{Pathobiology of Germ Cell Tumors and their Developmental Potential}

\subsection{Normal Physiology of Embryonic and Germ Cell Development}

In a simple way, for full human development to take place, the omnipotent zygote needs to undergo a program of successive restrictions of pluripotency, which is tightly regulated. However, and for assuring maintenance of the species, totipotency of the germ cell lineage must be essentially preserved [52].

Primordial germ cells (PGCs), the precursors of the various maturation stages of the germ cell lineage, undergo a process of specification, proliferation and, finally, migration along the midline of the body (explaining the topography of extragonadal GCTs), from the yolk sac, via the hindgut and towards the genital ridge, where sex determination subsequently occurs. Once arriving at the genital ridges they are referred to as gonocytes, which further differentiate into pre-spermatogonia or oocytes depending on the chromosomal constitution, on the action of the major player $S R Y$ gene and on the gonadal microenvironment, through a complex downstream signaling cascade [53,54]. During these processes of migration and maturation, an epigenetic 'reset' is warranted, in the form of early global DNA demethylation. This marks the start of the genomic imprinting (GI) cycle. GI (uncovered by Solter and Surani in 1984 [55-58]) refers to somatic inheritance of epigenetic marks, independently from the Mendelian laws of inheritance; in other words, it allows for some genes to be expressed depending on the parent (maternal or paternal) of origin, thanks to parental-specific DNA methylation and histone modifications [59]. A biparental GI is necessary for full development of the zygote, as is a specifically methylated intact genome with $\mathrm{X}$ chromosome inactivation in females. After fertilization takes place, the zygote receives a haploid set of paternally imprinted chromosomes from the father and a haploid set of maternally imprinted chromosomes from the mother, originating a diploid zygote with biparental GI pattern, which is replicated throughout full development of the embryo. The zygote undergoes two waves of demethylation (active demethylation in the paternal pronucleus and passive demethylation of the maternal genome), followed by remethylation with onset in the inner cell mass of the developing embryo. In the germline, however, GI needs to be early erased during PGCs migration, by means of demethylation of $\mathrm{CpG}$ sites, allowing for genesis of germ cells with no parental-specific epigenetic modifications. Finally, later on, when the maturing germ cells arrive at the genital ridges and reach mitotic (in males, spermatogenesis) or meiotic (in females, oogenesis) arrest, a restoration of the uniparental sex-specific (maternal or paternal) GI occurs, by de novo methylation of relevant target gene, closing the cycle [60-64] (Figure 1). Besides GI, X chromosome reactivation can be also considered a marker of developmental stage which occurs in female germ cells before oogenesis starts [65-67].

A full understanding of all stages of embryonic development and germ line establishment is the cornerstone of conceiving a unifying model for the pathogenesis of GCTs, where the developmental potential of each tumor entity is determined by the developmental state of the originating cell. This is an appealing model, as GCTs are truly in the crossroads between cancer and developmental biology [50,68]. For instance, it is easy to conceive that type III GCTs (which refer to STs) have a developmental potential restricted to postpubertal, premeiotic, spermatogenic cells (spermatogonium/spermatocytes) and display a GI pattern that is partially to completely paternal, while on the other hand type IV GCTs (which include dermoid cysts) derive from activated oocytes/ovum incapable of supporting the development of extraembryonic tissues, presenting with a GI status that is partially to completely maternal. Also, type V GCTs (which refer to hydatidiform moles), derive from an empty ovum that is subsequently fertilized by one sperm, hence presenting an exclusively paternal GI pattern, having no ability to give rise to somatic tissues. 


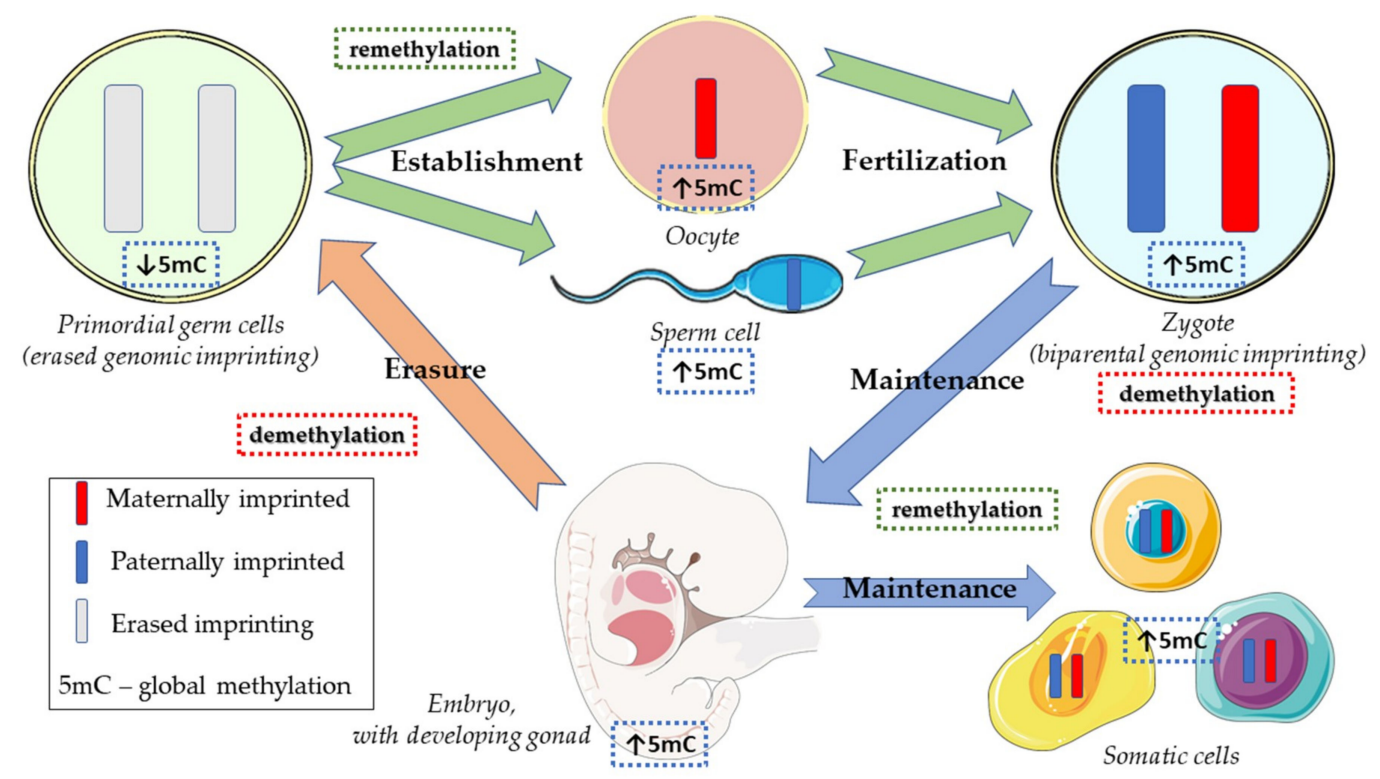

Figure 1. Cycle of genomic imprinting and global methylation.

\subsection{Type II Germ Cell Tumors of the Testis}

\subsubsection{Developmental Potential}

According to the proposed and above-mentioned model [50], errors in regulation of the developmental potential of embryonic stem and early PGCs may give rise essentially to extragonadal tumors early in life, whereas deregulation of the developmental potential already in the germline originates a multitude of tumors preferentially located in the gonads which are primarily diagnosed after childhood. In practice, this unifying model for GCTs enables them to be classified according to their developmental capabilities, and categorized in groups sharing common features, such as epidemiology, anatomical site distribution, cytogenetic abnormalities and epigenetic (de)regulation mechanisms like GI profile.

Regarding type II GCTs, the same developmental proximity is maintained; they have the broadest developmental potential (being in fact omnipotent) and comprise two major groups of neoplasms, the SEs (also referred to as dysgerminoma and germinoma in the ovary and in the brain, respectively), which derive from PGCs/gonocytes delayed in their maturation and constitute the so-called 'default pathway'; and the NSTs, which arise when a neoplastic PGC/gonocyte (either from GCNIS or overt SE) undergoes a process of reprogramming, leading to the formation of a totipotent EC cell. In turn, the latter has the capacity of originating tumor components representative of all lineages, including the extra-embryonal YST and choriocarcinoma $(\mathrm{CH})$, and the somatic-derived $\mathrm{TE}$, which includes somatic tissues from the three germ layers in varying degrees of maturation (i.e., pluripotent). A combination of any of these components leads to the formation of mixed tumors [69-71] (Figure 2).

In the early developmental stage of type II TGCTs, there is a continuum from a delay in maturation of gonocytes, pre-GCNIS and GCNIS; in the latter stage the neoplastic gonocytes are located in a territory known as spermatogonial niche, and consistently fail to switch off and hence express OCT3/4 (a transcription factor expressed both in normal PGCs and embryonic stem cells as well as in their neoplastic counterparts, SEs and ECs), usually in conjunction with expression of TSPY and presence KITLG (illustrating once again that TGCTs are developmental cancers, not due to accumulation of mutations but instead thanks to deregulation of expression of critical differentiation-related proteins) [72,73]. GCNIS (first discovered in 1972 by Skakkebaek [74]) virtually always progresses to overt TGCT (50\% at five years and 70\% at seven years [75]), passing through an intermediate stage in the 'default pathway' of intratubular SE before turning into a fully invasive SE. 
An escape from the 'default pathway' occurs through reprogramming of a SE cell, either intratubular or invasive, leading to emergence of an EC cell and originating NST components [76]. It remains to be proven whether all GCNIS will become invasive tumors.

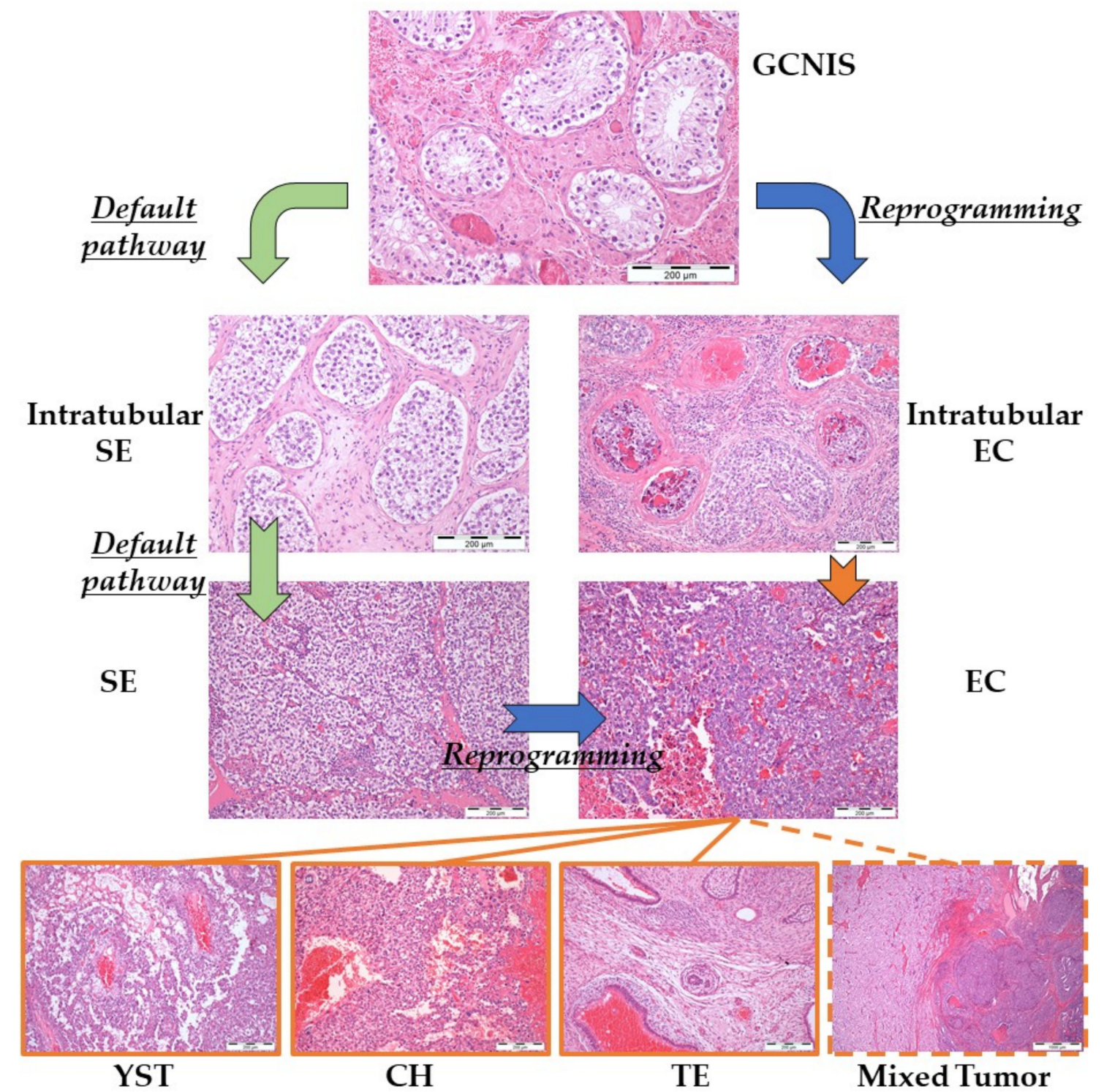

Figure 2. Pathogenesis of type II testicular germ cell tumors. Abbreviations: $\mathrm{CH}$-choriocarcinoma; EC-embryonal carcinoma; GCNIS-germ cell neoplasia in situ; SE-seminoma; TE-teratoma; YST-yolk sac tumor.

\subsubsection{Brief Pathogenetic Overview}

Type II GCTs are always malignant. Most (>90\%) arise in the testis (GCNIS-related postpubertal-type tumors), the rest occurring in dysgenetic gonads and in extragonadal sites [3]. Type II TGCTs are the most common malignancies in Caucasian males aged between 25 and 45 years-old in Western populations; of these, slightly more than $50 \%$ are pure SEs, the second most common being mixed tumors [4]. About 25\% of these tumors are expected to be due to familial susceptibility [77]. Also, they are consistently peritriploid, being characterized by gains of the short arm of chromosome 12 (frequently in the form of isochromosome 12p, [i(12p)]) [78,79], which makes sense considering that these tumors undergo a prolonged period of karyotype evolution since the intratubular phases of tumor development. Polyploidization, in addition to a hypomethylated genome, contribute to 
chromosomal instability in these neoplasms, which further drives tumor progression [80]; however, mutations and amplifications of oncogenes are rather rare in TGCTs, with KIT mutation being the most common, especially in SEs and in bilateral cases [81-83]. In fact, recent work by Dorssers et al. [84] has showed, by use of whole genome and targeted-sequencing, that NSTs are initiated by genome duplication, followed by chromosome copy number alterations in cancer stem cells, with very low accumulation of somatic mutations, even in cases resistant to therapy. Metastatic tumors show, in fact, very little overlap with the originating primary tumor and precursor lesions, meaning that treatment of recurrences deserve therapies targeted at their specific molecular landscape.

While differences in incidence across several regions of the globe demonstrate the relevance of environmental factors in their genesis, contrasting incidence rates in distinct ethnic groups of the same populations underline the contribution of genetic factors-in sum, the role of the aforementioned 'genvironmental' model [85].

\section{Taking Advantage of the Developmental Model: Biomarkers for Clinical Implementation}

\subsection{Use of High-Throughput Methodologies}

All seven subtypes of GCTs are derived from germ cells in distinct maturation stages and with distinct methylation profiles. A way to both support and study this tumorigenesis model has necessarily to pass through implementation of high-throughput, genome-wide methodologies. The implementation of techniques such as whole genome sequencing (WGS), whole exome sequencing (WES), targeted sequencing, RNA-sequencing (RNA-seq), miR profiling, methylation profiling/arrays and proteomics, and their combination (with proper exclusion of contaminants such as blood cells, stromal cells, immune cells, and compensation for other confounders), will open the door for clarifying findings of previous studies and for uncovering novel disease biomarkers. Some of these methodologies have already been employed in some studies and will be discussed in the following section.

\subsection{The Role of Epigenetics}

Epigenetics encompasses an array of processes that change gene expression without altering the DNA sequence, leading to a change in phenotype without changing the genotype. It comprises covalent modifications of DNA (such as DNA methylation), histone variants, histone I post-translational modifications, and non-coding RNAs (ncRNAs). DNA methylation, one of the most studied mechanisms, occurs by addition of methyl groups to the fifth carbon of cytosines, occurring preferentially at $\mathrm{CpG}$ sites, which are unevenly distributed in the genome-being concentrated in the so-called CpG islands. Differential methylation of gene promoters ultimately affects gene expression. Similarly, a number of ncRNAs are involved in the dynamic and environmentally sensitive regulation of gene expression. These molecules are known to interact (directly or indirectly) with the other established epigenetic mechanisms and can also directly interfere with messenger RNA (mRNA); this way, they can be seen as an extension of the complex epigenetic network, establishing important bridges between related modifications and truly influencing gene expression [86-88]. In this review, we will be focusing on methylation and a subtype of ncRNAs—-the microRNAs (miRs).

\subsubsection{Methylation-Based Biomarkers Relating to the Developmental Model}

X-chromosome inactivation (also known as lyonization [89]), a process limited to germ cells in the male, opens the way for uncovering novel biomarkers in TGCTs, namely concerning X-inactive specific transcript (XIST) gene, which is mapped to the X-chromosome inactivation center (XIC). In females, XIST (a long non-coding RNA [lnc-RNA] encoded from one of the $\mathrm{X}$ chromosomes, which is triggered when in cis) is responsible for inactivation (by inducing methylation of X-linked genes) of the extra $\mathrm{X}$ chromosome (compensating for the increased dosage of $\mathrm{X}$-linked genes when compared to male individuals) $[90,91]$. The fact that TGCTs of the adult testis (SEs and NSTs) often show supernumerary 
$X$ chromosomes suggests that XIST might also be expressed in these tumors. Indeed, both GCNIS and overt TGCTs have been shown to express XIST (contrarily to lower expression in normal testicular parenchyma with active spermatogenesis), which effectively rendered methylation of the $\mathrm{X}$-chromosome gene coding for androgen receptor (AR) [92]. One might say, then, that $\mathrm{X}$ inactivation by XIST allows the tolerance of an excessive gain of X chromosomes in TGCTs, particularly in SEs, which show higher expression than NSTs, meaning that this differentiation-dependent mechanism of inactivation is indeed preserved and functional in these neoplasms [93]. In this regard, Looijenga et al. findings [92] reflect, once again, a developmental model for TGCTs, with GCNIS and SEs showing XIST expression still not accompanied by methylation of the inactive $\mathrm{X}$ chromosome (a status typical of early germ cells), with more differentiated NSTs exhibiting both XIST expression and methylation of the inactive $\mathrm{X}$ chromosome (similar to female and extraembryonic tissues), and finally ECs displaying an intermediate pattern between the two.

TGCTs are stated to be hypomethylated when compared to other somatic-derived cancers, which makes it difficult to uncover methylation-based biomarkers for TGCTs, especially for more undifferentiated forms such as SEs. However, demethylated-based biomarkers might constitute a good strategy for these tumors [94-96]. In TGCTs, XIST, which has de advantage of being expressed specifically in male germ cells, is frequently hypomethylated at its $5^{\prime}$ end independently of its expression (but more in a differentiation-dependent manner), while in somatic cells its expression is regulated by methylation of its promoter (hypermethylation blocks XIST expression, resulting in an active $X$ chromosome). In this line, Kawakami et al. [97] very elegantly characterized the $5^{\prime}$ end of XIST by bisulfite sequencing and identified regions I to VI, with 56 CpG sites. In their work, region IV was found to be the most promising (consistently demethylated), and primers for the respective methylated and unmethylated sequence were designed for conventional polymerase chain reaction (PCR). Region IV was frequently unmethylated in TGCTs, especially in SEs and patients with advanced disease, and no demethylated signals were detected in somatic cancers in males (serum samples of kidney and bladder cancer patients). The authors explained the finding of some methylated signals in TGCTs as probably due to contamination with other cells. Investing in exploring these demethylated XIST fragments as biomarkers for TGCTs diagnosis in liquid biopsies is promising, especially if performed in larger cohorts and if novel detection methods with higher sensitivity and specificity are employed. These unmethylated fragments might prove very useful in the future for follow-up of SE patients, for which no available and reliable marker exist thus far [98]. In another study Ushida et al. [99] analyzed the methylation status of DNA repetitive elements in TGCTs, including LINE1 and Alu repeats located at the $5^{\prime}$ end of both E-Cadherin (CDH1) and XIST. By use of bisulfite sequencing and combined bisulfite restriction analysis (COBRA), the authors compared the (de)methylation profile of both TGCT cell lines, TGCT human tissues and somatic-derived cancers (kidney cancer cell lines and testicular lymphoma tissues), showing that LINE1 was highly hypomethylated in both SEs and NSTs; on the other hand, the two chosen Alu elements were differentially methylated between SE and NST samples (being mainly hypomethylated in the former and methylated in the latter). Despite somatic-derived neoplasms also exhibited partial demethylation of these regions (perhaps reflecting the commonly accepted hypomethylation pattern of DNA repetitive elements in cancers in general $[100,101])$, the degree of demethylation was not as pronounced as in TGCT samples, hypothesizing that the genesis of these tumors and the mechanisms underlying maintenance of demethylation of repetitive elements might differ among somatic and germ cell-derived neoplasms. Indeed, since PGCs undergo GI erasure (including erasure of methylation in LINE1 and Alu repeats [61]) and since SEs are composed of cells resembling PGCs/gonocytes, the (de)methylation profile observed in SEs might be specifically related to this resemblance and not to global demethylation observed in other cancer subtypes. Finally, the authors reported partial demethylation also in non-cancerous testicular parenchyma adjacent to TGCTs (without evidence of GCNIS); this somewhat unexpected finding is possibly due to epigenetic abnormalities related to defects in spermatogenesis and those occurring in stromal cells, similar to previous findings in gastric cancer [102]. These findings 
might point towards an impact of field-cancerization, with cancer-associated stromal cells sharing epigenetic changes with the accompanying tumor epithelial cells, and being biologically different from normal stroma unrelated to the tumor bulk. Similarly, in testes with impaired spermatogenesis, epigenetic aberrations (including demethylation) might have already taken place, despite no evidence of a germ cell lesion (invasive or precursor).

The promoter methylation status of several candidate genes has been assessed in various individual studies on TGCTs (reviewed in [103]), both in patients' tissue and plasma cohorts and cell lines [104-119]. Some focused on genes involved in stages of embryonic development (such as CRIPTO [105] and OCT3/4 [116]), others on genes having a tumor-suppressor role in a variety of neoplasms (such as RASFF1A [107,120]), others coding for DNA repair proteins (such as MGMT [109]) and others explored cancer-testis antigens (CTAs, such as PRAME [119]). Studies differ largely in methodologies employed (and related sensitivity and specificity), patient selection and samples studied (including distinct control samples and proportion of tumor subtypes), so they should be compared with caution. Some of these genes were indeed included in the DMRs picked up by genome-wide analyses [121], shedding more light on the findings of these studies.

Following the evidence that germ cells show transient erasure of GI, Killian et al. [122] explored the GI status of TGCTs by use of genome-wide DNA methylation analysis. In their study, the authors used only pure type II TGCT forms and neighboring testicular tissue without evidence of GCNIS. Besides performing somatic copy number aberrations (SCNA) analysis (requiring the gain of the short arm of chromosome 12 as an inclusion criteria), the authors introduced an adjunct technique to methylation profiling (450K Infinium bead-array), by using lymphoid compensation (LC). This lymphoid-compensated global methylation assessment might indeed prove very useful, as SEs, and sometimes also NSTs, are characterized by a prominent lymphoid infiltrate which contaminates the sample and confounds the results, possibly explaining the non-complete erasure observed in this tumor subtype (in which almost complete erasure would be expected). The authors confirmed, indeed, that LC resulted in shifting the peak methylation of SEs selectively close to zero, unmasking the true and whole erasure of these tumors. This way, the authors uncovered a hypomethylation locus which proved to be consistently present in TGCTs (both SEs and NSTs), corresponding to hypomethylation of the DPPA3 (also known as STELLA) gene promoter. This maternal-effect gene implicated in protecting parental imprints from erasure in the post-fertilization demethylation process, is expressed in both TGCTs and PGCs [123], and was shown to be hypomethylated in TGCTs (irrespective of the histology-SEs or NSTs-reflecting the pattern observed in PGCs), but always (hyper)methylated in all tested somatic tissues. Interestingly, this promoter shows no CpG islands. This pattern of erasure and expression is maintained despite the occurrence of de novo methylation, meaning that DPPA3 escapes differentiation-related methylation. This points out that DPPA3 might constitute a promising biomarker for TGCTs. Also in that study, methylation patterns of neighboring tissue were dependent on spermatogenic proficiency. Analysis of GI revealed hypermethylation of HM13 in NSTs and subtype-specific hypermethylation of H19 in TEs, while SEs (like GCNIS) were globally GI-erased, implying that focal methylation observed in NST samples might occur de novo after erasure, as suggested in other studies [124]. This might be of interest in the prediction of development of residual mature TE in case of patients with NST treated with chemotherapy [125]. Additionally, the authors explored differentially methylated genes among the various pure tumor entities: SEs, ECs, YSTs, CHs, and TEs.

In another study, Rijlaarsdam et al. [121] extensively profiled 91 GCTs (of subtypes I-IV, including males and females) and four GCT cell lines (representative of type II GCTs) using the HumanMethylation450 BeadChip (450K array, Illumina). After data processing (assuring exclusion of confounders such as cross hybridization, SNPs, poor probe performance) a total of 437,882 valid probes were employed, with additional annotation including small nuclear RNAs (snRNAs) and miRs, repetitive elements and imprinted segments. Ultimately, differentially methylated genomic regions were uncovered, allowing for clustering tumor subtypes according to their methylation 
profile. For instance, the most remarkable methylation differences were found between the cluster composed of SEs, dysgerminomas and STs (found to be globally hypomethylated) and the one composed of ECs, NSTs, and type I TEs (hypermethylated). Methylation profiling also allowed for discrimination of individual tumor subtypes. Interestingly, the analysis depicted little similarity between GCT human tissues and GCT-representative cell lines, which warrants caution when employing these in vitro models in methylation-based analyses. Furthermore, a number of GCT methylation-related genes were confirmed and/or uncovered with these analyses. With this study, by studying DMRs in a genome-wide manner, the authors truly provided insight into GCTs biology and developmental genesis, further supporting a developmental model for these tumors. In yet another study, Noor et al. [126] explored methylation and expression profiles of GCT cell lines using the same HumanMethylation450 BeadChip (450K array, Illumina) and the Affymetrix GeneChip Human Genome U133 Plus 2.0 Array, disclosing that the hypermethylation status observed in YSTs is localized to certain $\mathrm{CpG}$ islands in a small proportion of genes ( $\mathrm{CpG}$ island methylator phenotype), whereas for ECs and TEs methylation was more disperse. With this study the authors identified a wide list of genes differentially methylated between different cell lines and an inverse correlation with respective expression was established.

Cheung et al. [111] further studied epigenetic changes of ECs. In their study, they have profiled six pure ECs (metastatic and non-metastatic) with methylated DNA immunoprecipitation (MeDIP) followed by DNA-tiling hybridization (using Human Tiling Array 2.0R Chips), identifying hypermethylated DMRs in this tumor subtype, including $X$ - and Y-linked genes and others related to metabolism. Follow-up on these studies might lead to identification of biomarkers for diagnosing this aggressive tumor subtype.

More recently, an integrated analysis of TGCTs was produced by combining high-dimensional 'omics' assays (genomics, epigenomics, transcriptomics, and proteomics) [127]. This study included 137 TGCTs from 133 patients and confirmed the remarkably distinct global methylation status (using the above mentioned $450 \mathrm{~K}$ array) of different histological subtypes of TGCTs, again employing LC for methylation (after which the methylated peak was maintained in NSTs, while the intermediate methylation peaks disappeared in SEs). The study also depicted that ECs display methylation at the so-called $\mathrm{CpH}$ sites (non-canonical cytosine sites), a finding that even correlated with the amount of EC component, in line with the data of Killian et al. [88]. Both SEs (especially those with KIT mutations) and the majority of NSTs disclosed lack of methylation at imprinting sites. Finally, the analyses identified methylation of tumor suppressor genes already explored in other studies (see below), such as $B R C A 1$, and recognized RAD51C silencing in NSTs. As both genes are implicated in homologous recombination (HR) DNA repair pathway, these findings seem to indicate a role of this pathway in TGCTs.

\subsubsection{MicroRNAs Relating to the Developmental Model}

Control of pluripotency, early development and, subsequently, the development of GCNIS cells implies the expression of a number of biomarkers which may ultimately be used for diagnostic purposes, including messenger RNAs (mRNAs), protein players and also ncRNAs, such as miRs [128]. miRs are part of the small ncRNA (sncRNA) family, which means they are composed of less than $200 \mathrm{nt}$. Being the most studied, biologically relevant and versatile ncRNAs, they play important roles in many physiological and cancer-related processes, and they do so by dynamically regulating gene expression $[129,130]$. RNA-based biomarkers such as miRs display many advantages over protein-based ones, namely higher sensitivity and specificity (PCR techniques versus antibody-based techniques) and lower cost (as each protein requires a different antibody); and also over DNA-based biomarkers, as they are able to reflect dynamic cellular states and some of them are able to circulate stably in plasma and/or serum [131]. This has attracted attention towards miRs as biomarkers suitable for testing in liquid biopsies of cancer patients, for both diagnostic, prognostic, and predictive purposes [132]. This is particularly important in TGCTs, as commonly used serum markers 
(beta subunit of the human chorionic gonadotropin ( $\beta$-HCG), alpha-fetoprotein (AFP), and lactate dehydrogenase (LDH)) have limited diagnostic performance, especially in certain tumor subtypes such as SE and EC [133]. In this vein, significant effort has been invested in translating miR testing to the clinics, hence the numerous publications in the field (Figure 3).

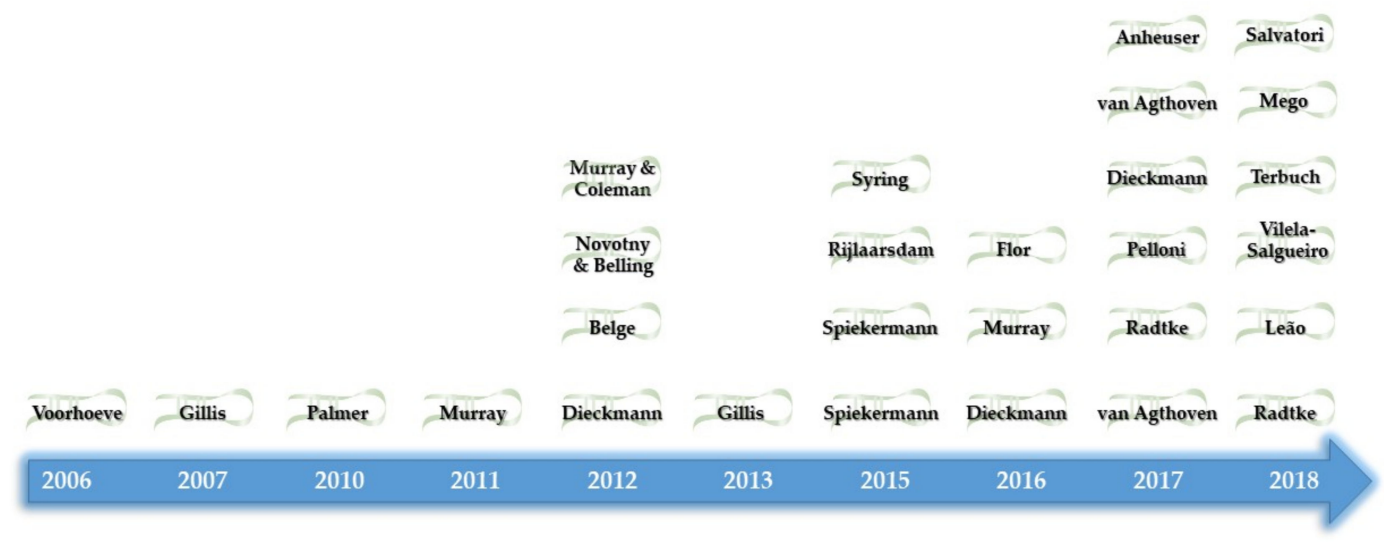

Figure 3. Chronological view of most relevant publications regarding microRNAs in testicular germ cell tumors (see text for details).

Voorhoeve et al. [134] were pioneers in identifying miRs that function as oncogenes (oncomiRs) in TGCTs by use of a miR library; they uncovered miR-372 and miR-373 role in neutralizing p53 function, by directly inhibiting the expression of the LATS2 tumor suppressor. This mechanism constitutes an explanation for tumor progression in TGCTs, which typically show absence of p53 mutations (i.e., they harbor wild-type p53). Gillis et al. [135] pursued a high throughput screen of 156 miRs in GCT tissues and cell lines, confirming the relevance of the miR-371-373 cluster. Also, they demonstrated variations in miR expression relating to degree of maturation, again establishing a parallelism between GCTs development and embryogenesis, allowing for discrimination of tumor subtypes. Another study also profiled 615 miRs in GCTs, again confirming the value of miR-371 373 and miR-372 clusters, which were elevated in all histological subtypes, both in adult and pediatric patients [136]. These miRs were also documented to be overexpressed in GCNIS tissues [137]. Vilela-Salgueiro et al. [138] also examined TGCT tissues and showed miR-371a-3p discriminated TGCTs from normal testicular parenchyma with high sensitivity and specificity, rendering an area under the curve (AUC) of 0.99. Additionally, higher expression levels of this miR was apparent in SEs compared to NSTs, and also among individual NST subtypes, with tumor samples showing a decreasing expression of miR-371a-3p in parallel with tumor differentiation. The authors have also showed that miR-371a-3p was able to discriminate TE tissue samples (including pure TE and TE component isolated from mixed tumors, with diverse degrees of maturation) from normal testis, although in serum this could not be confirmed so far, which might impair its use as a biomarker, particularly in predicting residual pure TE after chemotherapy (see below) [138-140].

Expression of these promising miR clusters was early pursued in serum and plasma samples. Indeed, Murray et al. [141] soon documented that the most relevant members of the miR-371 373 and miR-372 clusters were elevated at diagnosis in the serum of a four-year-old boy with a YST, and that levels decreased after surgery and chemotherapy, opening the way for exploring these biomarkers in this line [142,143]. Indeed, since then, numerous publications exploring the potential of these miR clusters have been published and extended the findings of this sole case report into large cohorts of patients representative of various tumor entities [144,145]. Dieckmann et al. [146] further innovated by measuring miR-371-3 directly from testicular vein blood, which directly drains from the tumor; not surprisingly, the latter samples showed higher expression levels when compared to cubital vein-derived blood. The authors also measured the expression of this miR in tissues, but levels 
showed no correlation with the ones in serum. This was also reported by the Looijenga group [128,147]. The clinical utility of measuring serum miR-371a-3p was, hence, demonstrated [148].

Methodologies for detection of these miRs in serum evolved; Gillis et al. [147] used the targeted serum miR (TSmiR) test in GCTs and healthy control males, and showed overexpression of miR-371/372/373/367 in GCT patients, which decreased towards baseline after treatment, disclosing $98 \%$ sensitivity. Also, there was a trend for higher expression levels of these miRs in patients with metastases, pointing towards an association with tumor burden. Soon, novel miRs were also uncovered by high-throughput methods, including miR-511,-26b, -769, -23a, -106b, -365, -598, -340, and let-7a [149]. Spiekermann et al. [150] also described that miR-371-3 expression levels might be assessed without the need for an endogenous control if experiments were performed under controlled conditions. Other bodily fluids were soon tested for miR-371a-3p expression levels: high expression levels were depicted in pleural effusions and seminal plasma of patients, but not in urine samples [151]. However, another study showed that miR-142 was upregulated in seminal plasma from TGCT patients, but that miR-371-3 (along with miR-34b) were downregulated compared to controls, contrarily to the previous study [152]. High expression levels were also depicted in hydrocele fluid surrounding tumors [153] and also in cerebral spinal fluid (CSF) of pediatric patients with extragonadal malignant GCTs, allowing for discrimination from intracranial non-GCTs and allowing detection of relapses with high sensitivity and specificity [154]. To date, the miR with the best overall performance in serum samples was shown to be miR-371a-3p (with a sensitivity of $88.7 \%$ and specificity of $93.4 \%$ ); also, expression levels correlated with relapse and dropped after treatment [155], and may additionally be used for detecting patients with GCNIS, possibly guiding the decision to perform a testicular biopsy in this context [156]. miR-371a-3p expression was also shown to outperform classical serum markers in detecting disease relapse, except in TEs $[140,157]$.

The largest series evaluated thus far identified (with ampTSmiR test) miR-371a-3p, 373-3p, and 367-3p as highly sensitive and specific in TGCTs diagnosis (joint AUC of 0.96) [139]. More recently the work of Leão et al. [158] provided answers to a clinically relevant scenario, which is the detection of residual disease post-chemotherapy, as there are no validated markers for predicting viable disease and up to $50 \%$ of cases show only fibrosis and necrosis. This way, a biomarker for predicting viable disease is desirable, perhaps avoiding unnecessary surgery and related morbidity. In their work, it was shown that miR-371a-3p discriminated viable disease with an AUC of 0.87. Further studies on this subject are, however, necessary for clinical implementation to take place. Finally, Radtke et al. [159] analyzed stage I TGCT patients and demonstrated that miR-371a-3p has a very short half-life (less than $12 \mathrm{~h}$ ), decaying very rapidly in the following three days after orchiectomy. Also, Mego et al. [160,161] reported the clinical utility of using miR-371a-3p plasma levels in predicting patient outcome in a population of TGCT patients set to be submitted to first line chemotherapy (higher levels associating with higher tumor burden and disease extent and negative levels culminating in better overall and progression-free survival).

All in all, miRs have shown great potential as biomarkers of both type I and type II GCTs, and also of GCNIS, and they are promising means for diagnosing and monitoring these patients. Their possible role as therapeutic targets is still largely unexplored and might constitute a promising way of avoiding cytotoxic treatments and its long-term side effects in such young patients [18]. A recent paper from Salvatori et al. [162] has used a mouse model for showing that plasma levels of miRs 371/302/C19MC were accurate in detecting undifferentiated and malignant components arising in xenografts derived from mice injected with human pluripotent stem cell (hPSC) lines and human malignant GCT cell lines. This study supports that these miRs might predict the emergence of malignancy in patients undergoing transplantation of hPSCs as a means of therapy, which thus far could only be determined by classical histological evaluation of TEs [163-165].

Besides methylation-related data, the already mentioned integrated study [127] depicted differentially expressed miRs (miR-sequencing (miR-seq) data) among tumor subtypes: it introduced the miR-519 cluster as being overexpressed in ECs (probably negatively regulating transcripts in 
this tumor subtype) and further confirmed miR-371a-3p value as a TGCT biomarker across subtypes (with the possible exception of TEs). It also disclosed miR-375 overexpression in TEs and YSTs, but not in ECs and SEs, meaning that it might complement miR-371a-3p expression assessment, especially in serum samples.

A summary of the mentioned studies on TGCT biomarkers regarding both methylation and miRs is depicted in Table 4.

Table 4. Summary of studies on testicular germ cell tumor biomarkers regarding methylation and microRNAs.

\begin{tabular}{|c|c|c|c|c|}
\hline Methodology & Sample Type & Major Findings & Year & Author \\
\hline \multicolumn{5}{|l|}{ Methylation } \\
\hline $\begin{array}{c}\text { Bisulfite } \\
\text { sequencing; PCR }\end{array}$ & $\begin{array}{c}\text { Tissues }(\mathrm{n}=31 \text { TGCTs }) \text { and } \\
\text { plasma }(\mathrm{n}=25 \text { TGCT samples, } \\
\mathrm{n}=24 \text { non-TGCT samples) }\end{array}$ & $\begin{array}{l}\text { XIST region IV frequently } \\
\text { unmethylated in TGCTs, } \\
\text { especially in SEs }\end{array}$ & 2004 & Kawakami et al. \\
\hline $\begin{array}{l}\text { Bisulfite } \\
\text { sequencing; } \\
\text { COBRA }\end{array}$ & $\begin{array}{c}\text { Tissues }(\mathrm{n}=14 \text { TGCTs, } \mathrm{n}=10 \\
\text { adjacent testicular parenchyma, } \\
\mathrm{n}=3 \text { non-TGCTs) and TGCT cell } \\
\text { lines }\end{array}$ & $\begin{array}{l}\text { LINE1 hypomethylated in both } \\
\text { SEs and NSTs; XIST and CDH1 } \\
\text { mainly hypomethylated in SEs } \\
\text { and methylated in NSTs }\end{array}$ & 2011 & Ushida et al. \\
\hline qMS-PCR & $\begin{array}{l}\text { Tissues }(\mathrm{n}=161 \text { TGCTs, } \\
\mathrm{n}=16 \text { controls })\end{array}$ & $\begin{array}{c}\text { Differential methylation of } \\
\text { CRIPTO, HOXA9, MGMT, } \\
\text { RASSF1A and SCGB3A1 gene } \\
\text { promoters among TGCT subtypes }\end{array}$ & 2018 & Costa et al. \\
\hline $\begin{array}{l}\text { Genome-wide } \\
\text { DNA methylation } \\
\text { analysis }\end{array}$ & $\begin{array}{l}\text { Tissues ( } \mathrm{n}=130 \text { TGCTs, } \mathrm{n}=128 \\
\text { benign neighboring testes) }\end{array}$ & $\begin{array}{l}\text { DPPA3 is hypomethylated in both } \\
\text { SEs and NSTs; hypermethylation } \\
\text { of HM13 in NSTs and } \\
\text { subtype-specific } \\
\text { hypermethylation of H19 in TEs }\end{array}$ & 2016 & Killian et al. \\
\hline $\begin{array}{l}\text { Genome-wide } \\
\text { DNA methylation } \\
\text { analysis }\end{array}$ & $\begin{array}{c}\text { Tissues }(\mathrm{n}=91 \mathrm{GCTs}) \text { and GCT } \\
\text { cell lines }\end{array}$ & $\begin{array}{l}\text { SEs, dysgerminomas and STs are } \\
\text { globally hypomethylated, } \\
\text { while ECs, NSTs and type I TEs } \\
\text { are hypermethylated }\end{array}$ & 2015 & Rijlaarsdam et al. \\
\hline $\begin{array}{l}\text { Genome-wide } \\
\text { DNA methylation } \\
\text { analysis; RT-qPCR }\end{array}$ & GCT cell lines & $\begin{array}{c}\text { Localized hypermethylation } \\
\text { status in YSTs vs. disperse } \\
\text { hypermethylation status in ECs } \\
\text { and TEs }\end{array}$ & 2015 & Noor et al. \\
\hline $\begin{array}{l}\text { MeDIP; DNA-tiling } \\
\text { hybridization; } \\
\text { RT-qPCR; IHC }\end{array}$ & Tissues $(n=6$ ECs $)$ & $\begin{array}{c}\text { Hypermethylated DMRs in ECs } \\
\text { (X- and Y-linked genes, } \\
\text { genes related to metabolism) }\end{array}$ & 2016 & Cheung et al. \\
\hline $\begin{array}{l}\text { Genome-wide } \\
\text { DNA methylation } \\
\text { analysis }\end{array}$ & Tissues $(\mathrm{n}=137$ TGCTs) & $\begin{array}{l}\text { ECs display methylation at } \mathrm{CpH} \\
\text { sites; methylation of } B R C A 1 \text { and } \\
\text { RAD51C silencing in NSTs }\end{array}$ & 2018 & Shen et al. \\
\hline \multicolumn{5}{|l|}{ MicroRNAs } \\
\hline miR library & NA & $\begin{array}{l}\text { miR-372 and miR-373 netralize } \\
\text { p53 (oncomiRs) }\end{array}$ & 2006 & Voorhoeve et al. \\
\hline $\begin{array}{l}\text { High-throughput } \\
\text { screening of } 156 \\
\text { miRs; qPCR }\end{array}$ & GCT tissues $(n=69)$ and cell lines & $\begin{array}{l}\text { Relevance of miR-371-373 cluster; } \\
\text { association with differentiation }\end{array}$ & 2007 & Gillis et al. \\
\hline $\begin{array}{l}\text { High-throughput } \\
\text { screening of } 615 \\
\text { miRs; RT-qPCR }\end{array}$ & $\begin{array}{l}\text { Pediatric malignant GCTs, } \\
\text { controls and GCT cell lines } \\
(n=48)\end{array}$ & $\begin{array}{l}\text { Overexpression of miR-371 373 } \\
\text { and miR-372 clusters in all } \\
\text { tumor subtypes }\end{array}$ & 2010 & Palmer et al. \\
\hline Multiplex PCR & $\begin{array}{c}\text { Serum }(n=1) \text { of a four-year-old } \\
\text { boy }\end{array}$ & $\begin{array}{l}\text { First report of utility of serum } \\
\text { miRs in GCTs (miR-371-373 and } \\
\text { miR-302 clusters); decrease } \\
\text { after treatment }\end{array}$ & 2011 & Murray et al. \\
\hline RT-qPCR & $\begin{array}{l}\text { Serum }(n=12 \text { patients, } \\
\qquad n=11 \text { controls })\end{array}$ & $\begin{array}{l}\text { Overexpression of miR-371-3 in } \\
\text { patients and decrease after } \\
\text { treatment }\end{array}$ & 2012 & Belge et al. \\
\hline RT-qPCR & Serum ( $\mathrm{n}=8$ malignant GCTs $)$ & $\begin{array}{l}\text { Additional specificity of using } \\
\text { miR-367-3p }\end{array}$ & 2012 & $\begin{array}{l}\text { Murray and } \\
\text { Coleman }\end{array}$ \\
\hline
\end{tabular}


Table 4. Cont

\begin{tabular}{|c|c|c|c|c|}
\hline Methodology & Sample Type & Major Findings & Year & Author \\
\hline \multicolumn{5}{|l|}{ Methylation } \\
\hline RT-qPCR & $\begin{array}{c}\text { Serum }(\mathrm{n}=24 \text { GCTs, } \mathrm{n}=17 \\
\text { controls }) \text { and GCT tissues }(\mathrm{n}=15)\end{array}$ & $\begin{array}{c}\text { miR-371 373 measured in TVB in } \\
6 \text { patients (higher levels); } \\
\text { no correlation with levels } \\
\text { in tissues }\end{array}$ & 2012 & Dieckmann et al. \\
\hline $\begin{array}{l}\text { miR array; } \\
\text { RT-qPCR }\end{array}$ & GCNIS tissue samples $(\mathrm{n}=12)$ & $\begin{array}{l}\text { Identification of miRs unique to } \\
\text { GCNIS cells }\end{array}$ & 2012 & $\begin{array}{l}\text { Novotny and } \\
\text { Belling et al. }\end{array}$ \\
\hline TSmiR & $\begin{array}{c}\text { Serum }(\mathrm{n}=80 \text { GCTs, } \mathrm{n}=47 \\
\text { controls, } \mathrm{n}=12 \text { non-GCT masses) }\end{array}$ & $\begin{array}{c}\text { miR-371/372/373/367 panel with } \\
98 \% \text { sensitivity in diagnosis; } \\
\text { higher expression levels in } \\
\text { metastatic patients }\end{array}$ & 2013 & Gillis et al. \\
\hline RT-qPCR & $\begin{array}{l}\text { Serum (testing cohort: } \mathrm{n}=30 \\
\text { patients and } \mathrm{n}=18 \text { controls; } \\
\text { validation cohort: } \mathrm{n}=76 \text { patients, } \\
\qquad \mathrm{n}=84 \text { controls) }\end{array}$ & $\begin{array}{c}\text { miR-367-3p, miR-371a-3p, } \\
\text { miR372-3p and miR-373-3p } \\
\text { overexpressed in patients; } \\
\text { miR-371-a-3p showing } 84.7 \% \\
\text { sensitivity and } 99 \% \text { specificity } \\
\text { in diagnosis }\end{array}$ & 2015 & Syring et al. \\
\hline RT-qPCR & $\begin{array}{c}\text { Serum }(\mathrm{n}=25 \text { GCTs, } 6 \text { GCNIS, } \\
\mathrm{n}=24 \text { non-testicular malignancies, } \\
\mathrm{n}=20 \text { controls }), \text { seminal plasma } \\
(\mathrm{n}=5), \text { urine }(\mathrm{n}=3) \text { and pleural } \\
\text { effusions }(\mathrm{n}=1)\end{array}$ & $\begin{array}{l}\text { miR-371a-3p detected in seminal } \\
\text { plasma and pleural effusions, } \\
\text { but not in urine; confirmation of } \\
\text { its value in serum }\end{array}$ & 2015 & Spiekermann et al. \\
\hline $\begin{array}{l}\text { High-throughput } \\
\text { screening of } 750 \\
\text { miRs; RT-qPCR }\end{array}$ & $\begin{array}{l}\text { Serum }(\mathrm{n}=14 \mathrm{GCTs} \\
\mathrm{n}=11 \text { controls })\end{array}$ & $\begin{array}{l}\text { Confirmation of the relevance of } \\
\text { miR-371-373 cluster; novel } \\
\text { relevant miRs identified }\end{array}$ & 2015 & Rijlaarsdam et al. \\
\hline RT-qPCR & $\begin{array}{l}\text { Serum }(\mathrm{n}=25 \text { TGCTs, } \mathrm{n}=4 \\
\text { non-TGCTs, } \mathrm{n}=17 \text { controls) }\end{array}$ & $\begin{array}{c}\text { Suggestion that normalization } \\
\text { (relative quantification) is not } \\
\text { required when } \\
\text { quantifying miR-371-3 }\end{array}$ & 2015 & Spiekermann \\
\hline RT-qPCR & $\begin{array}{l}\text { Serum and cerebral spinal fluid } \\
(\mathrm{n}=45 \text { each }) \text { of } 25 \\
\text { pediatric patients }\end{array}$ & $\begin{array}{l}\text { Four serum microRNA panel } \\
\text { (miR-371a-3p, miR-372-3p, } \\
\text { miR-373-30 and miR-367-3p) with } \\
\text { high sensitivity and specificity in } \\
\text { discriminating intracranial GCT } \\
\text { vs. non-GCT malignancies; } \\
\text { first demonstration of } \\
\text { relapse detection }\end{array}$ & 2016 & Murray et al. \\
\hline RT-qPCR & $\begin{array}{l}\text { GCT tissues and serum } \\
\quad(n=25 \text { patients })\end{array}$ & $\begin{array}{l}\text { C19MC cluster overexpressed in } \\
\text { aggressive subtypes }\end{array}$ & 2016 & Flor et al. \\
\hline RT-qPCR & $\begin{array}{l}\text { Tumor surrounding hydroceles } \\
(n=9) \text { and serum }(n=64 \text { GCTs })\end{array}$ & $\begin{array}{l}\text { Hydroceles showing high levels of } \\
\text { miR-371a-3p; association with } \\
\text { tumor size; confirmed the value of } \\
\text { miR-371a-3p in follow-up } \\
\text { (relapse detection) }\end{array}$ & 2016 & Dieckmann et al. \\
\hline ampTSmiR & $\begin{array}{l}\text { Serum }(\mathrm{n}=250 \text { TGCTs, } \mathrm{n}=60 \\
\text { non-TGCTs, } \mathrm{n}=104 \text { controls) }\end{array}$ & $\begin{array}{l}\text { Largest series tested; panel } \\
\text { composed of miR-371a-3p, } \\
\text { miR-373-3p and miR-367-3p with } \\
90 \% \text { sensitivity and } \\
91 \% \text { specificity }\end{array}$ & 2017 & van Agthoven et al. \\
\hline RT-qPCR & $\begin{array}{c}\text { Serum ( } \mathrm{n}=312 \text { consecutive } \\
\text { patients with testicular disease) }\end{array}$ & $\begin{array}{c}\text { Elevated levels aided in detection } \\
\text { of clinically silent GCTs } \\
\text { and metastases }\end{array}$ & 2017 & Anheuser et al. \\
\hline RT-qPCR & $\begin{array}{l}\text { Serum and seminal plasma }(\mathrm{n}=48 \\
\text { patients, } \mathrm{n}=28 \text { controls })\end{array}$ & $\begin{array}{l}\text { miR-371a-3p suggested as a poor } \\
\text { biomarker in seminal plasma, } \\
\text { contrarily to miR-142 }\end{array}$ & 2017 & Peloni et al. \\
\hline RT-qPCR & $\begin{array}{l}\text { Serum }(\mathrm{n}=166 \mathrm{GCTs} \\
\mathrm{n}=106 \text { controls })\end{array}$ & $\begin{array}{l}\text { miR-371a-3p shows the best } \\
\text { performance in TGCT detection } \\
(88.7 \% \text { sensitivity, } \\
93.4 \% \text { specificity })\end{array}$ & 2017 & Dieckmann et al. \\
\hline RT-qPCR & Serum ( $\mathrm{n}=27$ GCNIS) & $\begin{array}{l}\text { miR-371a-3p overexpressed in } \\
\text { GCNIS patients }\end{array}$ & 2017 & Radtke et al. \\
\hline ampTSmiR & $\begin{array}{l}\text { Serum }(\mathrm{n}=1 \mathrm{SE}, \mathrm{n}=5 \mathrm{NST}) \text { of } \\
\text { patients with } \\
\text { relapse } / \text { residual disease }\end{array}$ & $\begin{array}{l}\text { miR-371a-3p outperformed } \\
\text { classical protein markers in } \\
\text { detection of disease relapse, } \\
\text { except for mature TE }\end{array}$ & 2017 & van Agthoven et al. \\
\hline RT-qPCR & $\begin{array}{l}\text { Tissues }(\mathrm{n}=119 \text { TGCTs, } \\
\mathrm{n}=15 \text { controls })\end{array}$ & $\begin{array}{l}\text { miR-371a-3p discriminated TGCTs } \\
\text { from controls with } 92 \% \text { sensitivity } \\
\text { and } 93 \% \text { specificity; decreasing } \\
\text { expression with tumor } \\
\text { differentiation; TEs discriminated } \\
\text { from controls }\end{array}$ & 2018 & Vilela-Salgueiro et al \\
\hline
\end{tabular}


Table 4. Cont.

\begin{tabular}{|c|c|c|c|c|}
\hline Methodology & Sample Type & Major Findings & Year & Author \\
\hline \multicolumn{5}{|l|}{ Methylation } \\
\hline ampTSmiR & Serum $(\mathrm{n}=82$ TGCTs $)$ & $\begin{array}{c}\text { miR-371a-3p discriminates viable } \\
\text { disease post-chemotherapy } \\
\text { (AUC }=0.87)\end{array}$ & 2018 & Leão et al. \\
\hline RT-qPCR & Serum (24 TGCTs, clinical stage I) & $\begin{array}{l}\text { miR-371a-3p has a very short } \\
\text { half-life }(<12 \mathrm{~h})\end{array}$ & 2018 & Radtke et al. \\
\hline RT-qPCR & $\begin{array}{c}\text { Serum }(\mathrm{n}=10 \text { TGCT patients with } \\
\text { relapse) }\end{array}$ & $\begin{array}{c}\text { Confirmed miR-371a-3p value in } \\
\text { detecting relapses }\end{array}$ & 2018 & Terbuch et al. \\
\hline ampTSmiR & $\begin{array}{c}\text { Plasma ( } \mathrm{n}=199 \text { TGCTs, before } \\
\text { chemotherapy) }\end{array}$ & $\begin{array}{l}\text { miR-371a-3p predicts prognosis in } \\
\text { chemotherapy naïve patients }\end{array}$ & 2018 & Mego et al. \\
\hline $\begin{array}{l}\text { Teratoma assay } \\
\text { (mouse model) }\end{array}$ & Plasma of mice & $\begin{array}{c}\text { Value of miR-371 family members } \\
\text { in detecting undifferentiated and } \\
\text { potentially malignant elements } \\
\text { present in xenografts }\end{array}$ & 2018 & Salvatori et al. \\
\hline $\begin{array}{l}\text { miR-sequencing } \\
\text { data }\end{array}$ & Tissues $(\mathrm{n}=137$ TGCTs) & $\begin{array}{c}\text { miR-519 cluster overexpressed in } \\
\text { ECs; miR-375 overexpressed in } \\
\text { TEs and YSTs }\end{array}$ & 2018 & Shen et al. \\
\hline
\end{tabular}

Abbreviations: AR-androgen-receptor; AUC-area under the curve; COBRA-combined bisulfite restriction analysis; DMR — differentially methylated region; EC-embryonal carcinoma; GCTs-germ cell tumors; MeDIP—-methylated DNA immunoprecipitation; miR—microRNA; NST—non-seminomatous tumor; qMS-PCR - quantitative methylation-specific polymerase chain reaction; RT-qPCR-real-time quantitative polymerase chain reaction; SE-seminoma; ST—-spermatocytic tumor; TE—-teratoma; TGCTs—testicular germ cell tumors; TVB-testicular vein blood; YST_-yolk sac tumor.

\section{Conclusions}

An overview of TGCTs from a developmental perspective was provided. This model underlies the rationale for continuing to uncover epigenetic biomarkers that can be translated to the clinical practice. This selection is powerful because of the consistency of the identified factors in crucial regulatory pathways during embryogenesis, retained in TGCTs, and GCTs in general.

An integrated model (Figure 4) for defining TGCTs as distinct subtypes, concerning both genetic, cytogenetic, and epigenetic biomarkers, is warranted. We have showed that both DNA methylation profiles and miRs expression differ greatly among histological TGCT subtypes, and their detection in liquid biopsies has proved its use, such as miR-371a-3p. Somatic mutations are scarce in TGCTs, and are present mainly in SE components, especially those concerning KIT (which define a specific subset of SEs). Extensive aneuploidy (and frequent presence of $i(12 p)$ ) is a hallmark of TGCTs, regardless the histologic type. Only by integrating all these factors can we reveal novel unappreciated diversity within TGCTs as clinical entities.

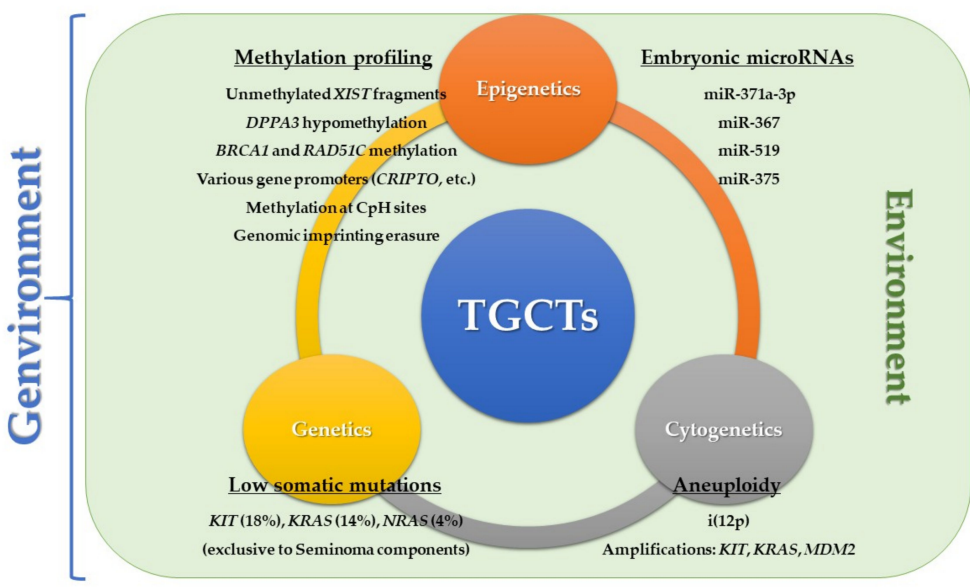

Figure 4. Integrative view of the genvironmental model, with focus on genetic, cytogenetic, and epigenetic factors, which are continuously modified and conditioned by the surrounding environment, ultimately determining the cell fate and tumor progression (see text for details). 
The use of novel high-throughput techniques will surely continue to open the door for characterizing new epigenetic aberrations in TGCTs, which can help us better understand their biology and, ultimately, be used for diagnostic and follow-up purposes.

Author Contributions: Original draft preparation, J.L.; review and editing, A.J.M.G., C.J., R.H., and L.H.J.L.

Funding: This research was funded by Fundação para a Ciência e Tecnologia-FCT (POCI-01-0145-FEDER-29043). J.L. is supported by an FCT—Fundação para a Ciência e Tecnologia—fellowship (SFRH/BD/132751/2017).

Conflicts of Interest: The authors declare no conflict of interest.

\begin{tabular}{|c|c|}
\hline \multicolumn{2}{|c|}{ Abbreviations } \\
\hline AFP & alpha-fetoprotein \\
\hline $\mathrm{AR}$ & androgen receptor \\
\hline$\beta-H C G$ & human chorionic gonadotropin, subunit $\beta$ \\
\hline $\mathrm{CH}$ & choriocarcinoma \\
\hline $\mathrm{CNV}$ & copy number variation \\
\hline COBRA & combined bisulfite restriction analysis \\
\hline DMR & differentially methylated regions \\
\hline DSD & disorders of sex development \\
\hline EC & embryonal carcinoma \\
\hline FTGCT & familial TGCT \\
\hline GCNIS & germ cell neoplasia in situ \\
\hline GCT & germ cell tumor \\
\hline GI & genomic imprinting \\
\hline GWAS & genome wide association \\
\hline hPSC & human pluripotent stem cell \\
\hline $\mathrm{HR}$ & homologous recombination \\
\hline LC & lymphoid compensation \\
\hline $\mathrm{LDH}$ & lactate dehydrogenase \\
\hline lncRNA & long non-coding RNA \\
\hline MeDIP & methylated DNA immunoprecipitation \\
\hline $\operatorname{miR}$ & microRNA \\
\hline ncRNA & non-coding RNA \\
\hline NST & non-seminomatous tumor \\
\hline PCR & polymerase chain reaction \\
\hline PGC & primordial germ cells \\
\hline RNA-seq & RNA sequencing \\
\hline SCNA & somatic copy number aberrations \\
\hline SE & seminoma \\
\hline sncRNA & small non-coding RNA \\
\hline SNP & single nucleotide polymorphisms \\
\hline snRNA & small nuclear RNA \\
\hline ST & spermatocytic tumor \\
\hline TDS & testicular dysgenesis syndrome \\
\hline $\mathrm{TE}$ & teratoma \\
\hline TGCT & testicular germ cell tumor \\
\hline TSmiR & targeted serum miR \\
\hline WES & whole exome sequencing \\
\hline WGS & whole genome sequencing \\
\hline XIC & X-chromosome inactivation center \\
\hline XIST & X-inactive specific transcript \\
\hline YST & yolk sac tumor \\
\hline
\end{tabular}




\section{References}

1. Moch, H.; Humphrey, P.; Ulbright, T.; Reuter, V. WHO Classification of Tumours of the Urinary System and Male Genital Organs, 4th ed.; IARC: Lyon, France, 2016.

2. De Angelis, R.; Sant, M.; Coleman, M.P.; Francisci, S.; Baili, P.; Pierannunzio, D.; Trama, A.; Visser, O.; Brenner, H.; Ardanaz, E.; et al. Cancer survival in Europe 1999-2007 by country and age: Results of EUROCARE-5-a population-based study. Lancet Oncol. 2014, 15, 23-34. [CrossRef]

3. Stang, A.; Trabert, B.; Wentzensen, N.; Cook, M.B.; Rusner, C.; Oosterhuis, J.W.; McGlynn, K.A. Gonadal and extragonadal germ cell tumours in the United States, 1973-2007. Int. J. Androl. 2012, 35, 616-625. [CrossRef] [PubMed]

4. Trabert, B.; Chen, J.; Devesa, S.S.; Bray, F.; McGlynn, K.A. International patterns and trends in testicular cancer incidence, overall and by histologic subtype, 1973-2007. Andrology 2015, 3, 4-12. [CrossRef] [PubMed]

5. Bray, F.; Ferlay, J.; Soerjomataram, I.; Siegel, R.L.; Torre, L.A.; Jemal, A. Global cancer statistics 2018: GLOBOCAN estimates of incidence and mortality worldwide for 36 cancers in 185 countries. CA Cancer J. Clin. 2018. [CrossRef] [PubMed]

6. Surveillance, Epidemiology, and End Results (SEER) Program. Research Data (1973-2015); National Cancer Institute, DCCPS, Surveillance Research Program: Rockville, MD, USA, 2018.

7. Shah, M.N.; Devesa, S.S.; Zhu, K.; McGlynn, K.A. Trends in testicular germ cell tumours by ethnic group in the United States. Int. J. Androl. 2007, 30, 206-213. [CrossRef] [PubMed]

8. Stevenson, S.M.; Lowrance, W.T. Epidemiology and Diagnosis of Testis Cancer. Urol. Clin. N. Am. 2015, 42, 269-275. [CrossRef] [PubMed]

9. Greiman, A.K.; Rosoff, J.S.; Prasad, S.M. Association of Human Development Index with global bladder, kidney, prostate and testis cancer incidence and mortality. BJU Int. 2017, 120, 799-807. [CrossRef]

10. Beyer, J.; Albers, P.; Altena, R.; Aparicio, J.; Bokemeyer, C.; Busch, J.; Cathomas, R.; Cavallin-Stahl, E.; Clarke, N.W.; Classen, J.; et al. Maintaining success, reducing treatment burden, focusing on survivorship: Highlights from the third European consensus conference on diagnosis and treatment of germ-cell cancer. Ann. Oncol. 2013, 24, 878-888. [CrossRef]

11. Curreri, S.A.; Fung, C.; Beard, C.J. Secondary malignant neoplasms in testicular cancer survivors. Urol. Oncol. 2015, 33, 392-398. [CrossRef]

12. Ostrowski, K.A.; Walsh, T.J. Infertility with Testicular Cancer. Urol. Clin. N. Am. 2015, 42, 409-420. [CrossRef]

13. Honecker, F.; Aparicio, J.; Berney, D.; Beyer, J.; Bokemeyer, C.; Cathomas, R.; Clarke, N.; Cohn-Cedermark, G.; Daugaard, G.; Dieckmann, K.P.; et al. ESMO Consensus Conference on testicular germ cell cancer: Diagnosis, treatment and follow-up. Ann. Oncol. 2018, 29, 1658-1686. [CrossRef]

14. O'Shaughnessy, M.J.; Feldman, D.R.; Carver, B.S.; Sheinfeld, J. Late Relapse of Testicular Germ Cell Tumors. Urol. Clin. N. Am. 2015, 42, 359-368. [CrossRef]

15. Hanna, N.H.; Einhorn, L.H. Testicular cancer-discoveries and updates. N. Engl. J. Med. 2014, 371, $2005-2016$. [CrossRef]

16. Rijlaarsdam, M.A.; Looijenga, L.H. An oncofetal and developmental perspective on testicular germ cell cancer. Semin. Cancer Biol. 2014, 29, 59-74. [CrossRef] [PubMed]

17. Litchfield, K.; Levy, M.; Orlando, G.; Loveday, C.; Law, P.J.; Migliorini, G.; Holroyd, A.; Broderick, P.; Karlsson, R.; Haugen, T.B.; et al. Identification of 19 new risk loci and potential regulatory mechanisms influencing susceptibility to testicular germ cell tumor. Nat. Genet. 2017, 49, 1133-1140. [CrossRef]

18. Cheng, L.; Albers, P.; Berney, D.M.; Feldman, D.R.; Daugaard, G.; Gilligan, T.; Looijenga, L.H.J. Testicular cancer. Nat. Rev. Dis. Primers 2018, 4, 29. [CrossRef]

19. Wang, Z.; McGlynn, K.A.; Rajpert-De Meyts, E.; Bishop, D.T.; Chung, C.C.; Dalgaard, M.D.; Greene, M.H.; Gupta, R.; Grotmol, T.; Haugen, T.B.; et al. Meta-analysis of five genome-wide association studies identifies multiple new loci associated with testicular germ cell tumor. Nat. Genet. 2017, 49, 1141-1147. [CrossRef] [PubMed]

20. Kharazmi, E.; Hemminki, K.; Pukkala, E.; Sundquist, K.; Tryggvadottir, L.; Tretli, S.; Olsen, J.H.; Fallah, M. Cancer Risk in Relatives of Testicular Cancer Patients by Histology Type and Age at Diagnosis: A Joint Study from Five Nordic Countries. Eur. Urol. 2015, 68, 283-289. [CrossRef] [PubMed]

21. Gundy, S.; Babosa, M.; Baki, M.; Bodrogi, I. Increased predisposition to cancer in brothers and offspring of testicular tumor patients. Pathol. Oncol. Res. 2004, 10, 197-203. [CrossRef] 
22. Kratz, C.P.; Mai, P.L.; Greene, M.H. Familial testicular germ cell tumours. Best Pract. Res. Clin. Endocrinol. Metab. 2010, 24, 503-513. [CrossRef]

23. Rorth, M.; Grigor, K.M.; Jorgensen, N.; Skakkebaek, N.E.; Rajpert-De Meyts, E. Contralateral biopsy in the management of testicular cancer: What we have learned and what we need to improve. Andrology 2015, 3, 99-101. [CrossRef] [PubMed]

24. Oosterhuis, J.W.; Stoop, H.; Dohle, G.; Boellaard, W.; van Casteren, N.; Wolffenbuttel, K.; Looijenga, L.H. A pathologist's view on the testis biopsy. Int. J. Androl. 2011, 34, e14-e19. [CrossRef] [PubMed]

25. Greene, M.H.; Mai, P.L.; Loud, J.T.; Pathak, A.; Peters, J.A.; Mirabello, L.; McMaster, M.L.; Rosenberg, P.; Stewart, D.R. Familial testicular germ cell tumors (FTGCT)—Overview of a multidisciplinary etiologic study. Andrology 2015, 3, 47-58. [CrossRef]

26. Cools, M.; Looijenga, L.H. Tumor risk and clinical follow-up in patients with disorders of sex development. Pediatr. Endocrinol. Rev. 2011, 9, 519-524.

27. Looijenga, L.H.; Hersmus, R.; Oosterhuis, J.W.; Cools, M.; Drop, S.L.; Wolffenbuttel, K.P. Tumor risk in disorders of sex development (DSD). Best Pract. Res. Clin. Endocrinol. Metab. 2007, 21, 480-495. [CrossRef]

28. Pleskacova, J.; Hersmus, R.; Oosterhuis, J.W.; Setyawati, B.A.; Faradz, S.M.; Cools, M.; Wolffenbuttel, K.P.; Lebl, J.; Drop, S.L.; Looijenga, L.H. Tumor risk in disorders of sex development. Sex. Dev. 2010, 4, 259-269. [CrossRef]

29. Hersmus, R.; van Bever, Y.; Wolffenbuttel, K.P.; Biermann, K.; Cools, M.; Looijenga, L.H. The biology of germ cell tumors in disorders of sex development. Clin. Genet. 2017, 91, 292-301. [CrossRef]

30. Van der Zwan, Y.G.; Biermann, K.; Wolffenbuttel, K.P.; Cools, M.; Looijenga, L.H. Gonadal maldevelopment as risk factor for germ cell cancer: Towards a clinical decision model. Eur. Urol. 2015, 67, 692-701. [CrossRef] [PubMed]

31. Looijenga, L.H.; Stoop, H.; Biermann, K. Testicular cancer: Biology and biomarkers. Virchows Arch. 2014, 464, $301-313$. [CrossRef] [PubMed]

32. Van Der Zwan, Y.G.; Stoop, H.; Rossello, F.; White, S.J.; Looijenga, L.H. Role of epigenetics in the etiology of germ cell cancer. Int. J. Dev. Biol. 2013, 57, 299-308. [CrossRef] [PubMed]

33. Chung, C.C.; Kanetsky, P.A.; Wang, Z.; Hildebrandt, M.A.; Koster, R.; Skotheim, R.I.; Kratz, C.P.; Turnbull, C.; Cortessis, V.K.; Bakken, A.C.; et al. Meta-analysis identifies four new loci associated with testicular germ cell tumor. Nat. Genet. 2013, 45, 680-685. [CrossRef]

34. Ruark, E.; Seal, S.; McDonald, H.; Zhang, F.; Elliot, A.; Lau, K.; Perdeaux, E.; Rapley, E.; Eeles, R.; Peto, J.; et al. Identification of nine new susceptibility loci for testicular cancer, including variants near DAZL and PRDM14. Nat. Genet. 2013, 45, 686-689. [CrossRef]

35. Kratz, C.P.; Han, S.S.; Rosenberg, P.S.; Berndt, S.I.; Burdett, L.; Yeager, M.; Korde, L.A.; Mai, P.L.; Pfeiffer, R.; Greene, M.H. Variants in or near KITLG, BAK1, DMRT1, and TERT-CLPTM1L predispose to familial testicular germ cell tumour. J. Med. Genet. 2011, 48, 473-476. [CrossRef] [PubMed]

36. Turnbull, C.; Rapley, E.A.; Seal, S.; Pernet, D.; Renwick, A.; Hughes, D.; Ricketts, M.; Linger, R.; Nsengimana, J.; Deloukas, P.; et al. Variants near DMRT1, TERT and ATF7IP are associated with testicular germ cell cancer. Nat. Genet. 2010, 42, 604-607. [CrossRef]

37. Mayer, F.; Stoop, H.; Sen, S.; Bokemeyer, C.; Oosterhuis, J.W.; Looijenga, L.H. Aneuploidy of human testicular germ cell tumors is associated with amplification of centrosomes. Oncogene 2003, 22, 3859-3866. [CrossRef] [PubMed]

38. Basten, S.G.; Davis, E.E.; Gillis, A.J.; van Rooijen, E.; Stoop, H.; Babala, N.; Logister, I.; Heath, Z.G.; Jonges, T.N.; Katsanis, N.; et al. Mutations in LRRC50 predispose zebrafish and humans to seminomas. PLoS Genet. 2013, 9, e1003384. [CrossRef]

39. Litchfield, K.; Levy, M.; Dudakia, D.; Proszek, P.; Shipley, C.; Basten, S.; Rapley, E.; Bishop, D.T.; Reid, A.; Huddart, R.; et al. Rare disruptive mutations in ciliary function genes contribute to testicular cancer susceptibility. Nat. Commun. 2016, 7, 13840. [CrossRef]

40. Skakkebaek, N.E.; Rajpert-De Meyts, E.; Main, K.M. Testicular dysgenesis syndrome: An increasingly common developmental disorder with environmental aspects. Hum. Reprod. 2001, 16, 972-978. [CrossRef]

41. Cook, M.B.; Akre, O.; Forman, D.; Madigan, M.P.; Richiardi, L.; McGlynn, K.A. A systematic review and meta-analysis of perinatal variables in relation to the risk of testicular cancer-Experiences of the mother. Int. J. Epidemiol. 2009, 38, 1532-1542. [CrossRef] [PubMed] 
42. Rajpert-De Meyts, E.; McGlynn, K.A.; Okamoto, K.; Jewett, M.A.; Bokemeyer, C. Testicular germ cell tumours. Lancet 2016, 387, 1762-1774. [CrossRef]

43. McGlynn, K.A.; Cook, M.B. Etiologic factors in testicular germ-cell tumors. Future Oncol. 2009, 5, 1389-1402. [CrossRef] [PubMed]

44. Giannandrea, F.; Fargnoli, S. Environmental Factors Affecting Growth and Occurrence of Testicular Cancer in Childhood: An Overview of the Current Epidemiological Evidence. Children 2017, 4, 1. [CrossRef] [PubMed]

45. Trabert, B.; Sigurdson, A.J.; Sweeney, A.M.; Strom, S.S.; McGlynn, K.A. Marijuana use and testicular germ cell tumors. Cancer 2011, 117, 848-853. [CrossRef]

46. Daling, J.R.; Doody, D.R.; Sun, X.; Trabert, B.L.; Weiss, N.S.; Chen, C.; Biggs, M.L.; Starr, J.R.; Dey, S.K.; Schwartz, S.M. Association of marijuana use and the incidence of testicular germ cell tumors. Cancer 2009, 115, 1215-1223. [CrossRef]

47. Friedman, N.B.; Moore, R.A. Tumors of the testis; a report on 922 cases. Mil. Surg. 1946, 99, 573-593. [PubMed]

48. Moch, H.; Cubilla, A.L.; Humphrey, P.A.; Reuter, V.E.; Ulbright, T.M. The 2016 WHO Classification of Tumours of the Urinary System and Male Genital Organs-Part A: Renal, Penile, and Testicular Tumours. Eur. Urol. 2016, 70, 93-105. [CrossRef] [PubMed]

49. Lobo, J.; Costa, A.L.; Vilela-Salgueiro, B.; Rodrigues, A.; Guimaraes, R.; Cantante, M.; Lopes, P.; Antunes, L.; Jeronimo, C.; Henrique, R. Testicular germ cell tumors: Revisiting a series in light of the new WHO classification and AJCC staging systems, focusing on challenges for pathologists. Hum. Pathol. 2018. [CrossRef] [PubMed]

50. Nogales, F.F.; Jimenez, R.E. Pathology and Biology of Human Germ Cell Tumors; Springer-Verlag GmbH: Berlin, Germany, 2017.

51. Oosterhuis, J.W.; Looijenga, L.H. Testicular germ-cell tumours in a broader perspective. Nat. Rev. Cancer 2005, 5, 210-222. [CrossRef]

52. Slack, J.M. Origin of stem cells in organogenesis. Science 2008, 322, 1498-1501. [CrossRef]

53. Dong, W.L.; Tan, F.Q.; Yang, W.X. Wnt signaling in testis development: Unnecessary or essential? Gene 2015, 565, 155-165. [CrossRef]

54. Windley, S.P.; Wilhelm, D. Signaling Pathways Involved in Mammalian Sex Determination and Gonad Development. Sex. Dev. 2015, 9, 297-315. [CrossRef] [PubMed]

55. Ferguson-Smith, A.C.; Bourc'his, D. The discovery and importance of genomic imprinting. eLife 2018, 7, e42368. [CrossRef] [PubMed]

56. McGrath, J.; Solter, D. Completion of mouse embryogenesis requires both the maternal and paternal genomes. Cell 1984, 37, 179-183. [CrossRef]

57. Surani, M.A.; Barton, S.C.; Norris, M.L. Development of reconstituted mouse eggs suggests imprinting of the genome during gametogenesis. Nature 1984, 308, 548-550. [CrossRef]

58. Barton, S.C.; Surani, M.A.; Norris, M.L. Role of paternal and maternal genomes in mouse development. Nature 1984, 311, 374-376. [CrossRef] [PubMed]

59. Hirasawa, R.; Feil, R. Genomic imprinting and human disease. Essays Biochem. 2010, 48, 187-200. [CrossRef] [PubMed]

60. Messerschmidt, D.M. Should I stay or should I go: Protection and maintenance of DNA methylation at imprinted genes. Epigenetics 2012, 7, 969-975. [CrossRef] [PubMed]

61. Popp, C.; Dean, W.; Feng, S.; Cokus, S.J.; Andrews, S.; Pellegrini, M.; Jacobsen, S.E.; Reik, W. Genome-wide erasure of DNA methylation in mouse primordial germ cells is affected by AID deficiency. Nature 2010, 463, 1101-1105. [CrossRef] [PubMed]

62. Reik, W.; Dean, W.; Walter, J. Epigenetic reprogramming in mammalian development. Science 2001, 293, $1089-1093$. [CrossRef]

63. Wang, L.; Zhang, J.; Duan, J.; Gao, X.; Zhu, W.; Lu, X.; Yang, L.; Zhang, J.; Li, G.; Ci, W.; et al. Programming and inheritance of parental DNA methylomes in mammals. Cell 2014, 157, 979-991. [CrossRef]

64. Hackett, J.A.; Sengupta, R.; Zylicz, J.J.; Murakami, K.; Lee, C.; Down, T.A.; Surani, M.A. Germline DNA demethylation dynamics and imprint erasure through 5-hydroxymethylcytosine. Science 2013, 339, 448-452. [CrossRef] [PubMed]

65. Payer, B.; Lee, J.T.; Namekawa, S.H. X-inactivation and X-reactivation: Epigenetic hallmarks of mammalian reproduction and pluripotent stem cells. Hum. Genet. 2011, 130, 265-280. [CrossRef] [PubMed] 
66. Ohhata, T.; Wutz, A. Reactivation of the inactive $\mathrm{X}$ chromosome in development and reprogramming. Cell. Mol. Life Sci. 2013, 70, 2443-2461. [CrossRef]

67. Seisenberger, S.; Peat, J.R.; Hore, T.A.; Santos, F.; Dean, W.; Reik, W. Reprogramming DNA methylation in the mammalian life cycle: Building and breaking epigenetic barriers. Phil. Trans. R. Soc. B Biol. Sci. 2013, 368, 20110330. [CrossRef] [PubMed]

68. Buljubasic, R.; Buljubasic, M.; Bojanac, A.K.; Ulamec, M.; Vlahovic, M.; Jezek, D.; Bulic-Jakus, F.; Sincic, N. Epigenetics and testicular germ cell tumors. Gene 2018, 661, 22-33. [CrossRef] [PubMed]

69. Cheng, L.; Lyu, B.; Roth, L.M. Perspectives on testicular germ cell neoplasms. Hum. Pathol. 2017, 59, 10-25. [CrossRef] [PubMed]

70. Williamson, S.R.; Delahunt, B.; Magi-Galluzzi, C.; Algaba, F.; Egevad, L.; Ulbright, T.M.; Tickoo, S.K.; Srigley, J.R.; Epstein, J.I.; Berney, D.M.; et al. The World Health Organization 2016 classification of testicular germ cell tumours: A review and update from the International Society of Urological Pathology Testis Consultation Panel. Histopathology 2017, 70, 335-346. [CrossRef] [PubMed]

71. Howitt, B.E.; Berney, D.M. Tumors of the Testis: Morphologic Features and Molecular Alterations. Surg. Pathol. Clin. 2015, 8, 687-716. [CrossRef] [PubMed]

72. Honecker, F.; Stoop, H.; de Krijger, R.R.; Chris Lau, Y.F.; Bokemeyer, C.; Looijenga, L.H. Pathobiological implications of the expression of markers of testicular carcinoma in situ by fetal germ cells. J. Pathol. 2004, 203, 849-857. [CrossRef]

73. Spoor, J.A.; Oosterhuis, J.W.; Hersmus, R.; Biermann, K.; Wolffenbuttel, K.P.; Cools, M.; Kazmi, Z.; Ahmed, S.F.; Looijenga, L.H.J. Histological Assessment of Gonads in DSD: Relevance for Clinical Management. Sex. Dev. 2018, 12, 106-122. [CrossRef]

74. Skakkebaek, N.E. Possible carcinoma-in-situ of the testis. Lancet 1972, 2, 516-517. [CrossRef]

75. Kier, M.G.; Lauritsen, J.; Almstrup, K.; Mortensen, M.S.; Toft, B.G.; Rajpert-De Meyts, E.; Skakkebaek, N.E.; Rorth, M.; von der Maase, H.; Agerbaek, M.; et al. Screening for carcinoma in situ in the contralateral testicle in patients with testicular cancer: A population-based study. Ann. Oncol. 2015, 26, 737-742. [CrossRef] [PubMed]

76. Oosterhuis, J.W.; Looijenga, L.H. The biology of human germ cell tumours: Retrospective speculations and new prospectives. Eur. Urol. 1993, 23, 245-250. [CrossRef] [PubMed]

77. Hemminki, K.; Li, X. Familial risk in testicular cancer as a clue to a heritable and environmental aetiology. Br. J. Cancer 2004, 90, 1765-1770. [CrossRef] [PubMed]

78. Oosterhuis, J.W.; Castedo, S.M.; de Jong, B.; Cornelisse, C.J.; Dam, A.; Sleijfer, D.T.; Schraffordt Koops, H. Ploidy of primary germ cell tumors of the testis. Pathogenetic and clinical relevance. Lab. Investig. 1989, 60, 14-21. [PubMed]

79. Atkin, N.B.; Baker, M.C. Specific chromosome change, i(12p), in testicular tumours? Lancet 1982, $2,1349$. [CrossRef]

80. Looijenga, L.H.; Zafarana, G.; Grygalewicz, B.; Summersgill, B.; Debiec-Rychter, M.; Veltman, J.; Schoenmakers, E.F.; Rodriguez, S.; Jafer, O.; Clark, J.; et al. Role of gain of 12p in germ cell tumour development. APMIS 2003, 111, 161-171. [CrossRef] [PubMed]

81. Litchfield, K.; Summersgill, B.; Yost, S.; Sultana, R.; Labreche, K.; Dudakia, D.; Renwick, A.; Seal, S.; Al-Saadi, R.; Broderick, P.; et al. Whole-exome sequencing reveals the mutational spectrum of testicular germ cell tumours. Nat. Commun. 2015, 6, 5973. [CrossRef] [PubMed]

82. Kemmer, K.; Corless, C.L.; Fletcher, J.A.; McGreevey, L.; Haley, A.; Griffith, D.; Cummings, O.W.; Wait, C.; Town, A.; Heinrich, M.C. KIT mutations are common in testicular seminomas. Am. J. Pathol. 2004, 164, 305-313. [CrossRef]

83. Looijenga, L.H.; de Leeuw, H.; van Oorschot, M.; van Gurp, R.J.; Stoop, H.; Gillis, A.J.; de Gouveia Brazao, C.A.; Weber, R.F.; Kirkels, W.J.; van Dijk, T.; et al. Stem cell factor receptor (c-KIT) codon 816 mutations predict development of bilateral testicular germ-cell tumors. Cancer Res. 2003, 63, 7674-7678.

84. Dorssers, L.C.; Gillis, A.J.; Stoop, H.; van Marion, R.; Nieboer, M.M.; van Riet, J.; van de Werken, H.J.; Oosterhuis, J.W.; de Ridder, J.; Looijenga, L.H. Molecular Heterogeneity and Early Metastatic Clone Selection in Testicular Germ Cell Cancer Development. bioRxiv 2018. [CrossRef]

85. Levine, H.; Afek, A.; Shamiss, A.; Derazne, E.; Tzur, D.; Zavdy, O.; Barchana, M.; Kark, J.D. Risk of germ cell testicular cancer according to origin: A migrant cohort study in 1,100,000 Israeli men. Int. J. Cancer 2013, 132, 1878-1885. [CrossRef] [PubMed]

86. Kim, J.K.; Samaranayake, M.; Pradhan, S. Epigenetic mechanisms in mammals. Cell. Mol. Life Sci. 2009, 66, 596-612. [CrossRef] [PubMed] 
87. Dupont, C.; Armant, D.R.; Brenner, C.A. Epigenetics: Definition, mechanisms and clinical perspective. Semin. Reprod. Med. 2009, 27, 351-357. [CrossRef] [PubMed]

88. Peschansky, V.J.; Wahlestedt, C. Non-coding RNAs as direct and indirect modulators of epigenetic regulation. Epigenetics 2014, 9, 3-12. [CrossRef] [PubMed]

89. Lyon, M. The gift of observation: An interview with Mary Lyon. Interview by Jane Gitschier. PLoS Genet. 2010, 6, e1000813.

90. Chaligne, R.; Heard, E. X-chromosome inactivation in development and cancer. FEBS Lett. 2014, 588, $2514-2522$. [CrossRef]

91. Gendrel, A.V.; Heard, E. Noncoding RNAs and epigenetic mechanisms during X-chromosome inactivation. Annu. Rev. Cell Dev. Biol. 2014, 30, 561-580. [CrossRef]

92. Looijenga, L.H.; Gillis, A.J.; van Gurp, R.J.; Verkerk, A.J.; Oosterhuis, J.W. X inactivation in human testicular tumors. XIST expression and androgen receptor methylation status. Am. J. Pathol. 1997, 151, 581-590.

93. Kawakami, T.; Okamoto, K.; Sugihara, H.; Hattori, T.; Reeve, A.E.; Ogawa, O.; Okada, Y. The roles of supernumerical $X$ chromosomes and XIST expression in testicular germ cell tumors. J. Urol. 2003, 169, 1546-1552. [CrossRef] [PubMed]

94. Smiraglia, D.J.; Szymanska, J.; Kraggerud, S.M.; Lothe, R.A.; Peltomaki, P.; Plass, C. Distinct epigenetic phenotypes in seminomatous and nonseminomatous testicular germ cell tumors. Oncogene 2002, 21, 3909-3916. [CrossRef]

95. Wermann, H.; Stoop, H.; Gillis, A.J.; Honecker, F.; van Gurp, R.J.; Ammerpohl, O.; Richter, J.; Oosterhuis, J.W.; Bokemeyer, C.; Looijenga, L.H. Global DNA methylation in fetal human germ cells and germ cell tumours: Association with differentiation and cisplatin resistance. J. Pathol. 2010, 221, 433-442. [CrossRef]

96. Netto, G.J.; Nakai, Y.; Nakayama, M.; Jadallah, S.; Toubaji, A.; Nonomura, N.; Albadine, R.; Hicks, J.L.; Epstein, J.I.; Yegnasubramanian, S.; et al. Global DNA hypomethylation in intratubular germ cell neoplasia and seminoma, but not in nonseminomatous male germ cell tumors. Mod. Pathol. 2008, 21, 1337-1344. [CrossRef] [PubMed]

97. Kawakami, T.; Okamoto, K.; Ogawa, O.; Okada, Y. XIST unmethylated DNA fragments in male-derived plasma as a tumour marker for testicular cancer. Lancet 2004, 363, 40-42. [CrossRef]

98. Looijenga, L.H.; Oosterhuis, J.W. Clinical value of the $\mathrm{X}$ chromosome in testicular germ-cell tumours. Lancet 2004, 363, 6-8. [CrossRef]

99. Ushida, H.; Kawakami, T.; Minami, K.; Chano, T.; Okabe, H.; Okada, Y.; Okamoto, K. Methylation profile of DNA repetitive elements in human testicular germ cell tumor. Mol. Carcinog. 2012, 51, 711-722. [CrossRef] [PubMed]

100. Pogribny, I.P.; Beland, F.A. DNA hypomethylation in the origin and pathogenesis of human diseases. Cell. Mol. Life Sci. 2009, 66, 2249-2261. [CrossRef] [PubMed]

101. Rodriguez, J.; Vives, L.; Jorda, M.; Morales, C.; Munoz, M.; Vendrell, E.; Peinado, M.A. Genome-wide tracking of unmethylated DNA Alu repeats in normal and cancer cells. Nucleic Acids Res. 2008, 36, 770-784. [CrossRef] [PubMed]

102. Jiang, L.; Gonda, T.A.; Gamble, M.V.; Salas, M.; Seshan, V.; Tu, S.; Twaddell, W.S.; Hegyi, P.; Lazar, G.; Steele, I.; et al. Global hypomethylation of genomic DNA in cancer-associated myofibroblasts. Cancer Res. 2008, 68, 9900-9908. [CrossRef] [PubMed]

103. Costa, A.L.; Lobo, J.; Jeronimo, C.; Henrique, R. The epigenetics of testicular germ cell tumors: Looking for novel disease biomarkers. Epigenomics 2017, 9, 155-169. [CrossRef]

104. Costa, A.L.; Moreira-Barbosa, C.; Lobo, J.; Vilela-Salgueiro, B.; Cantante, M.; Guimaraes, R.; Lopes, P.; Braga, I.; Oliveira, J.; Antunes, L.; et al. DNA methylation profiling as a tool for testicular germ cell tumors subtyping. Epigenomics 2018. [CrossRef]

105. Spiller, C.M.; Gillis, A.J.; Burnet, G.; Stoop, H.; Koopman, P.; Bowles, J.; Looijenga, L.H. Cripto: Expression, epigenetic regulation and potential diagnostic use in testicular germ cell tumors. Mol. Oncol. 2016, 10, 526-537. [CrossRef] [PubMed]

106. Smith-Sorensen, B.; Lind, G.E.; Skotheim, R.I.; Fossa, S.D.; Fodstad, O.; Stenwig, A.E.; Jakobsen, K.S.; Lothe, R.A. Frequent promoter hypermethylation of the O6-Methylguanine-DNA Methyltransferase (MGMT) gene in testicular cancer. Oncogene 2002, 21, 8878-8884. [CrossRef] [PubMed]

107. Koul, S.; Houldsworth, J.; Mansukhani, M.M.; Donadio, A.; McKiernan, J.M.; Reuter, V.E.; Bosl, G.J.; Chaganti, R.S.; Murty, V.V. Characteristic promoter hypermethylation signatures in male germ cell tumors. Mol. Cancer 2002, 1, 8. [CrossRef] 
108. Koul, S.; McKiernan, J.M.; Narayan, G.; Houldsworth, J.; Bacik, J.; Dobrzynski, D.L.; Assaad, A.M.; Mansukhani, M.; Reuter, V.E.; Bosl, G.J.; et al. Role of promoter hypermethylation in Cisplatin treatment response of male germ cell tumors. Mol. Cancer 2004, 3, 16. [CrossRef] [PubMed]

109. Martinelli, C.; Lengert, A.V.H.; Carcano, F.M.; Silva, E.C.A.; Brait, M.; Lopes, L.F.; Vidal, D.O. MGMT and CALCA promoter methylation are associated with poor prognosis in testicular germ cell tumor patients. Oncotarget 2017, 8, 50608-50617. [CrossRef] [PubMed]

110. Lind, G.E.; Skotheim, R.I.; Fraga, M.F.; Abeler, V.M.; Esteller, M.; Lothe, R.A. Novel epigenetically deregulated genes in testicular cancer include homeobox genes and SCGB3A1 (HIN-1). J. Pathol. 2006, 210, 441-449. [CrossRef]

111. Cheung, H.H.; Yang, Y.; Lee, T.L.; Rennert, O.; Chan, W.Y. Hypermethylation of genes in testicular embryonal carcinomas. Br. J. Cancer 2016, 114, 230-236. [CrossRef]

112. Amatruda, J.F.; Ross, J.A.; Christensen, B.; Fustino, N.J.; Chen, K.S.; Hooten, A.J.; Nelson, H.; Kuriger, J.K.; Rakheja, D.; Frazier, A.L.; et al. DNA methylation analysis reveals distinct methylation signatures in pediatric germ cell tumors. BMC Cancer 2013, 13, 313. [CrossRef]

113. Kato, N.; Tamura, G.; Fukase, M.; Shibuya, H.; Motoyama, T. Hypermethylation of the RUNX3 gene promoter in testicular yolk sac tumor of infants. Am. J. Pathol. 2003, 163, 387-391. [CrossRef]

114. Kato, N.; Shibuya, H.; Fukase, M.; Tamura, G.; Motoyama, T. Involvement of adenomatous polyposis coli (APC) gene in testicular yolk sac tumor of infants. Hum. Pathol. 2006, 37, 48-53. [CrossRef]

115. Van der Zwan, Y.G.; Rijlaarsdam, M.A.; Rossello, F.J.; Notini, A.J.; de Boer, S.; Watkins, D.N.; Gillis, A.J.; Dorssers, L.C.; White, S.J.; Looijenga, L.H. Seminoma and embryonal carcinoma footprints identified by analysis of integrated genome-wide epigenetic and expression profiles of germ cell cancer cell lines. PLoS ONE 2014, 9, e98330. [CrossRef]

116. De Jong, J.; Weeda, S.; Gillis, A.J.; Oosterhuis, J.W.; Looijenga, L.H. Differential methylation of the OCT3/4 upstream region in primary human testicular germ cell tumors. Oncol. Rep. 2007, 18, 127-132. [CrossRef] [PubMed]

117. Nettersheim, D.; Biermann, K.; Gillis, A.J.; Steger, K.; Looijenga, L.H.; Schorle, H. NANOG promoter methylation and expression correlation during normal and malignant human germ cell development. Epigenetics 2011, 6, 114-122. [CrossRef] [PubMed]

118. Brait, M.; Maldonado, L.; Begum, S.; Loyo, M.; Wehle, D.; Tavora, F.F.; Looijenga, L.H.; Kowalski, J.; Zhang, Z.; Rosenbaum, E.; et al. DNA methylation profiles delineate epigenetic heterogeneity in seminoma and non-seminoma. Br. J. Cancer 2012, 106, 414-423. [CrossRef]

119. Nettersheim, D.; Arndt, I.; Sharma, R.; Riesenberg, S.; Jostes, S.; Schneider, S.; Holzel, M.; Kristiansen, G.; Schorle, $\mathrm{H}$. The cancer/testis-antigen PRAME supports the pluripotency network and represses somatic and germ cell differentiation programs in seminomas. Br. J. Cancer 2016, 115, 454-464. [CrossRef] [PubMed]

120. Markulin, D.; Vojta, A.; Samarzija, I.; Gamulin, M.; Beceheli, I.; Jukic, I.; Maglov, C.; Zoldos, V.; Fucic, A. Association Between RASSF1A Promoter Methylation and Testicular Germ Cell Tumor: A Meta-analysis and a Cohort Study. Cancer Genom. Proteom. 2017, 14, 363-372.

121. Rijlaarsdam, M.A.; Tax, D.M.; Gillis, A.J.; Dorssers, L.C.; Koestler, D.C.; de Ridder, J.; Looijenga, L.H. Genome wide DNA methylation profiles provide clues to the origin and pathogenesis of germ cell tumors. PLoS ONE 2015, 10, e0122146. [CrossRef] [PubMed]

122. Killian, J.K.; Dorssers, L.C.; Trabert, B.; Gillis, A.J.; Cook, M.B.; Wang, Y.; Waterfall, J.J.; Stevenson, H.; Smith, W.I., Jr.; Noyes, N.; et al. Imprints and DPPA3 are bypassed during pluripotency- and differentiation-coupled methylation reprogramming in testicular germ cell tumors. Genome Res. 2016, 26, 1490-1504. [CrossRef]

123. Von Meyenn, F.; Reik, W. Forget the Parents: Epigenetic Reprogramming in Human Germ Cells. Cell 2015, 161, 1248-1251. [CrossRef] [PubMed]

124. Oliveros-Etter, M.; Li, Z.; Nee, K.; Hosohama, L.; Hargan-Calvopina, J.; Lee, S.A.; Joti, P.; Yu, J.; Clark, A.T. PGC Reversion to Pluripotency Involves Erasure of DNA Methylation from Imprinting Control Centers followed by Locus-Specific Re-methylation. Stem Cell Rep. 2015, 5, 337-349. [CrossRef] [PubMed]

125. Leao, R.; Nayan, M.; Punjani, N.; Jewett, M.A.S.; Fadaak, K.; Garisto, J.; Lewin, J.; Atenafu, E.G.; Sweet, J.; Anson-Cartwright, L.; et al. A New Model to Predict Benign Histology in Residual Retroperitoneal Masses After Chemotherapy in Nonseminoma. Eur. Urol. Focus. 2018. [CrossRef] [PubMed] 
126. Noor, D.A.M.; Jeyapalan, J.N.; Alhazmi, S.; Carr, M.; Squibb, B.; Wallace, C.; Tan, C.; Cusack, M.; Hughes, J.; Reader, T.; et al. Genome-wide methylation analysis identifies genes silenced in non-seminoma cell lines. NPJ Genom. Med. 2016, 1, 15009. [CrossRef]

127. Shen, H.; Shih, J.; Hollern, D.P.; Wang, L.; Bowlby, R.; Tickoo, S.K.; Thorsson, V.; Mungall, A.J.; Newton, Y.; Hegde, A.M.; et al. Integrated Molecular Characterization of Testicular Germ Cell Tumors. Cell Rep. 2018, 23, 3392-3406. [CrossRef] [PubMed]

128. Eini, R.; Dorssers, L.C.; Looijenga, L.H. Role of stem cell proteins and microRNAs in embryogenesis and germ cell cancer. Int. J. Dev. Biol. 2013, 57, 319-332. [CrossRef] [PubMed]

129. Anfossi, S.; Babayan, A.; Pantel, K.; Calin, G.A. Clinical utility of circulating non-coding RNAs-An update. Nat. Rev. Clin. Oncol. 2018, 15, 541-563. [CrossRef]

130. He, L.; Hannon, G.J. MicroRNAs: Small RNAs with a big role in gene regulation. Nat. Rev. Genet. 2004, 5, 522-531. [CrossRef] [PubMed]

131. Xi, X.; Li, T.; Huang, Y.; Sun, J.; Zhu, Y.; Yang, Y.; Lu, Z.J. RNA Biomarkers: Frontier of Precision Medicine for Cancer. Noncoding RNA 2017, 3, e9. [CrossRef]

132. Dominguez-Vigil, I.G.; Moreno-Martinez, A.K.; Wang, J.Y.; Roehrl, M.H.A.; Barrera-Saldana, H.A. The dawn of the liquid biopsy in the fight against cancer. Oncotarget 2018, 9, 2912-2922. [CrossRef]

133. Henrique, R.; Jeronimo, C. Testicular Germ Cell Tumors Go Epigenetics: Will miR-371a-3p Replace Classical Serum Biomarkers? Eur. Urol. 2017, 71, 221-222. [CrossRef]

134. Voorhoeve, P.M.; le Sage, C.; Schrier, M.; Gillis, A.J.; Stoop, H.; Nagel, R.; Liu, Y.P.; van Duijse, J.; Drost, J.; Griekspoor, A.; et al. A genetic screen implicates miRNA-372 and miRNA-373 as oncogenes in testicular germ cell tumors. Cell 2006, 124, 1169-1181. [CrossRef] [PubMed]

135. Gillis, A.J.; Stoop, H.J.; Hersmus, R.; Oosterhuis, J.W.; Sun, Y.; Chen, C.; Guenther, S.; Sherlock, J.; Veltman, I.; Baeten, J.; et al. High-throughput microRNAome analysis in human germ cell tumours. J. Pathol. 2007, 213, 319-328. [CrossRef] [PubMed]

136. Palmer, R.D.; Murray, M.J.; Saini, H.K.; van Dongen, S.; Abreu-Goodger, C.; Muralidhar, B.; Pett, M.R.; Thornton, C.M.; Nicholson, J.C.; Enright, A.J.; et al. Malignant germ cell tumors display common microRNA profiles resulting in global changes in expression of messenger RNA targets. Cancer Res. 2010, 70, 2911-2923. [CrossRef]

137. Novotny, G.W.; Belling, K.C.; Bramsen, J.B.; Nielsen, J.E.; Bork-Jensen, J.; Almstrup, K.; Sonne, S.B.; Kjems, J.; Rajpert-De Meyts, E.; Leffers, H. MicroRNA expression profiling of carcinoma in situ cells of the testis. Endocr. Relat. Cancer 2012, 19, 365-379. [CrossRef] [PubMed]

138. Vilela-Salgueiro, B.; Barros-Silva, D.; Lobo, J.; Costa, A.L.; Guimaraes, R.; Cantante, M.; Lopes, P.; Braga, I.; Oliveira, J.; Henrique, R.; et al. Germ cell tumour subtypes display differential expression of microRNA371a-3p. Phil. Trans. R. Soc. B Biol. Sci. 2018, 373, 20170338. [CrossRef]

139. Van Agthoven, T.; Looijenga, L.H.J. Accurate primary germ cell cancer diagnosis using serum based microRNA detection (ampTSmiR test). Oncotarget 2017, 8, 58037-58049. [CrossRef] [PubMed]

140. Van Agthoven, T.; Eijkenboom, W.M.H.; Looijenga, L.H.J. microRNA-371a-3p as informative biomarker for the follow-up of testicular germ cell cancer patients. Cell. Oncol. 2017, 40, 379-388. [CrossRef] [PubMed]

141. Murray, M.J.; Halsall, D.J.; Hook, C.E.; Williams, D.M.; Nicholson, J.C.; Coleman, N. Identification of microRNAs From the miR-371-373 and miR-302 clusters as potential serum biomarkers of malignant germ cell tumors. Am. J. Clin. Pathol. 2011, 135, 119-125. [CrossRef]

142. Belge, G.; Dieckmann, K.P.; Spiekermann, M.; Balks, T.; Bullerdiek, J. Serum levels of microRNAs miR-371-3: A novel class of serum biomarkers for testicular germ cell tumors? Eur. Urol. 2012, 61, 1068-1069. [CrossRef]

143. Murray, M.J.; Coleman, N. Testicular cancer: A new generation of biomarkers for malignant germ cell tumours. Nat. Rev. Urol. 2012, 9, 298-300. [CrossRef]

144. Syring, I.; Bartels, J.; Holdenrieder, S.; Kristiansen, G.; Muller, S.C.; Ellinger, J. Circulating serum miRNA (miR-367-3p, miR-371a-3p, miR-372-3p and miR-373-3p) as biomarkers in patients with testicular germ cell cancer. J. Urol. 2015, 193, 331-337. [CrossRef] [PubMed]

145. Flor, I.; Spiekermann, M.; Loning, T.; Dieckmann, K.P.; Belge, G.; Bullerdiek, J. Expression of microRNAs of C19MC in Different Histological Types of Testicular Germ Cell Tumour. Cancer Genom. Proteom. 2016, 13, 281-289.

146. Dieckmann, K.P.; Spiekermann, M.; Balks, T.; Flor, I.; Loning, T.; Bullerdiek, J.; Belge, G. MicroRNAs miR-371-3 in serum as diagnostic tools in the management of testicular germ cell tumours. Br. J. Cancer 2012, 107, 1754-1760. [CrossRef] [PubMed] 
147. Gillis, A.J.; Rijlaarsdam, M.A.; Eini, R.; Dorssers, L.C.; Biermann, K.; Murray, M.J.; Nicholson, J.C.; Coleman, N.; Dieckmann, K.P.; Belge, G.; et al. Targeted serum miRNA (TSmiR) test for diagnosis and follow-up of (testicular) germ cell cancer patients: A proof of principle. Mol. Oncol. 2013, 7, 1083-1092. [CrossRef]

148. Anheuser, P.; Radtke, A.; Wulfing, C.; Kranz, J.; Belge, G.; Dieckmann, K.P. Serum Levels of MicroRNA371a-3p: A Highly Sensitive Tool for Diagnosing and Staging Testicular Germ Cell Tumours: A Clinical Case Series. Urol. Int. 2017, 99, 98-103. [CrossRef] [PubMed]

149. Rijlaarsdam, M.A.; Van Agthoven, T.; Gillis, A.J.; Patel, S.; Hayashibara, K.; Lee, K.Y.; Looijenga, L.H. Identification of known and novel germ cell cancer-specific (embryonic) miRs in serum by high-throughput profiling. Andrology 2015, 3, 85-91. [CrossRef] [PubMed]

150. Spiekermann, M.; Dieckmann, K.P.; Balks, T.; Bullerdiek, J.; Belge, G. Is relative quantification dispensable for the measurement of microRNAs as serum biomarkers in germ cell tumors? Anticancer Res. 2015, 35, 117-121. [PubMed]

151. Spiekermann, M.; Belge, G.; Winter, N.; Ikogho, R.; Balks, T.; Bullerdiek, J.; Dieckmann, K.P. MicroRNA miR-371a-3p in serum of patients with germ cell tumours: Evaluations for establishing a serum biomarker. Andrology 2015, 3, 78-84. [CrossRef]

152. Pelloni, M.; Coltrinari, G.; Paoli, D.; Pallotti, F.; Lombardo, F.; Lenzi, A.; Gandini, L. Differential expression of miRNAs in the seminal plasma and serum of testicular cancer patients. Endocrine 2017, 57, 518-527. [CrossRef]

153. Dieckmann, K.P.; Spiekermann, M.; Balks, T.; Ikogho, R.; Anheuser, P.; Wosniok, W.; Loening, T.; Bullerdiek, J.; Belge, G. MicroRNA miR-371a-3p-A Novel Serum Biomarker of Testicular Germ Cell Tumors: Evidence for Specificity from Measurements in Testicular Vein Blood and in Neoplastic Hydrocele Fluid. Urol. Int. 2016, 97, 76-83. [CrossRef]

154. Murray, M.J.; Bell, E.; Raby, K.L.; Rijlaarsdam, M.A.; Gillis, A.J.; Looijenga, L.H.; Brown, H.; Destenaves, B.; Nicholson, J.C.; Coleman, N. A pipeline to quantify serum and cerebrospinal fluid microRNAs for diagnosis and detection of relapse in paediatric malignant germ-cell tumours. Br. J. Cancer 2016, 114, 151-162. [CrossRef] [PubMed]

155. Dieckmann, K.P.; Radtke, A.; Spiekermann, M.; Balks, T.; Matthies, C.; Becker, P.; Ruf, C.; Oing, C.; Oechsle, K.; Bokemeyer, C.; et al. Serum Levels of MicroRNA miR-371a-3p: A Sensitive and Specific New Biomarker for Germ Cell Tumours. Eur. Urol. 2017, 71, 213-220. [CrossRef] [PubMed]

156. Radtke, A.; Cremers, J.F.; Kliesch, S.; Riek, S.; Junker, K.; Mohamed, S.A.; Anheuser, P.; Belge, G.; Dieckmann, K.P. Can germ cell neoplasia in situ be diagnosed by measuring serum levels of microRNA371a-3p? J. Cancer Res. Clin. Oncol. 2017, 143, 2383-2392. [CrossRef] [PubMed]

157. Terbuch, A.; Adiprasito, J.B.; Stiegelbauer, V.; Seles, M.; Klec, C.; Pichler, G.P.; Resel, M.; Posch, F.; Lembeck, A.L.; Stoger, H.; et al. MiR-371a-3p Serum Levels Are Increased in Recurrence of Testicular Germ Cell Tumor Patients. Int. J. Mol. Sci. 2018, 19, 3130. [CrossRef] [PubMed]

158. Leao, R.; van Agthoven, T.; Figueiredo, A.; Jewett, M.A.S.; Fadaak, K.; Sweet, J.; Ahmad, A.E.; Anson-Cartwright, L.; Chung, P.; Hansen, A.; et al. Serum miRNA Predicts Viable Disease after Chemotherapy in Patients with Testicular Nonseminoma Germ Cell Tumor. J. Urol. 2018, 200, 126-135. [CrossRef] [PubMed]

159. Radtke, A.; Hennig, F.; Ikogho, R.; Hammel, J.; Anheuser, P.; Wulfing, C.; Belge, G.; Dieckmann, K.P. The Novel Biomarker of Germ Cell Tumours, Micro-RNA-371a-3p, Has a Very Rapid Decay in Patients with Clinical Stage 1. Urol. Int. 2018, 100, 470-475. [CrossRef]

160. Mego, M.; Agthoven, T.V.; Gronesova, P.; Chovanec, M.; Miskovska, V.; Mardiak, J.; Looijenga, L. Clinical utility of plasma miR-371a-3p in testicular germ cell tumors. J. Clin. Oncol. 2018, 36, e16540. [CrossRef]

161. Mego, M.; Agthoven, T.V.; Gronesova, P.; Chovanec, M.; Miskovska, V.; Mardiak, J.; Looijenga, L. Clinical utility of plasma miR-371a-3p in germ cell tumors. J. Cell. Mol. Med. 2018. [CrossRef] [PubMed]

162. Salvatori, D.C.F.; Dorssers, L.C.J.; Gillis, A.J.M.; Perretta, G.; van Agthoven, T.; Gomes Fernandes, M.; Stoop, H.; Prins, J.B.; Oosterhuis, J.W.; Mummery, C.; et al. The MicroRNA-371 Family as Plasma Biomarkers for Monitoring Undifferentiated and Potentially Malignant Human Pluripotent Stem Cells in Teratoma Assays. Stem Cell Rep. 2018, 11, 1493-1505. [CrossRef] [PubMed]

163. Muller, F.J.; Goldmann, J.; Loser, P.; Loring, J.F. A call to standardize teratoma assays used to define human pluripotent cell lines. Cell Stem Cell. 2010, 6, 412-414. [CrossRef] [PubMed] 
164. Damjanov, I.; Andrews, P.W. Teratomas produced from human pluripotent stem cells xenografted into immunodeficient mice-A histopathology atlas. Int. J. Dev. Biol. 2016, 60, 337-419. [CrossRef] [PubMed]

165. International Stem Cell Initiative. Assessment of established techniques to determine developmental and malignant potential of human pluripotent stem cells. Nat. Commun. 2018, 9, 1925. [CrossRef] [PubMed]

(c) 2019 by the authors. Licensee MDPI, Basel, Switzerland. This article is an open access article distributed under the terms and conditions of the Creative Commons Attribution (CC BY) license (http://creativecommons.org/licenses/by/4.0/). 